\title{
Ceramic Offering Trays in the Museo Egizio, Turin: Establishing Typologies and Locating Unprovenanced Specimens
}

Filippo Mi

Attempting to re-organise and discuss a rich ensemble of pottery offering trays from the Museo Egizio, this article offers a new contribution to the study of this class of objects. The totality of published and unpublished trays from the Museo is taken into consideration and divided according to provenance. Three groups are identified: a considerable number of trays from Schiaparelli's excavations in the Asyut necropolis; a group of trays from Gebelein; and a group of trays without provenance, and whose modalities of acquisition are uncertain. Each group is examined thoroughly and further subdivided based on stylistic and material characteristics. Common features and stylistic trends in trays from the same site and with the same provenance are identified. References to other trays from other museum collections or excavation reports help establish parallels and highlight common characteristics as well possible influences between neighbouring sites and regions. The attempt to reorganise the well-provenanced specimens within their archaeological context yields a better understanding of the distribution and popularity of this category of objects. Finally, the author proposes a plausible reassignment of a provenance to Museo Egizio specimens hitherto considered unprovenanced.

تساعد هذه المقالة على دراسة مجموعة من الفخاريات الموجودة في المتحف المصري حيث هنالك محاولة لإعادة تنظيم ومناقشة مجموعة غنية من الصواني الفخارية. تُؤخذ في عين الاعتبار جميع القطع الموجودة في المتحف التي تم النشر عنها أو تلك القطع التي لم يُنشر عنها أي مقالة مسبقاَ، ويتم تقسيمها حسب المصدر • تم تحديد ثلاث مجموعات: عدد كبير من الصواني

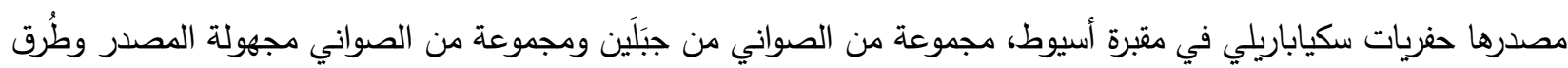
اقتتائها. يتم فحص كل مجموعة بدقة وتقسيمها على أساس خصائص الثكل والمادة. تُحدّد البِمات المشتركة للصواني من حيث الثكل ومن حيث الموقع والمصدر الواحد. تُساعد المقارنات مع صواني أخرى محفوظة ضمن مجموعات لمتاحف أخرى أو تقارير التتقيبات المختلفة في تحديد أوجه التثابه وإبراز الخصائص المشتركة بالإضافة إلى الكثف عن التأثيرات المحتملة بين المواقع والمناطق المجاورة. تؤدي محاولة إعادة تتظيم اللقى وتثبيتها بدقة ضمن سياقها الأثري إلى فهم أفضل لاستعمالاتها ومدى شعبيتها. أخيراً، يَتقرح المؤلّف إعادة تحديد مصدر عينات المتحف المصري التي كانت تُعتبر حتى الآن غير مؤكدة.

\section{Introduction}

Over the last few years, latching onto a renewed interest among scholars in the study of pottery offering trays and soul houses, the author has conducted a study of the objects belonging to this class in Turin's Museo Egizio. The museum holds a collection of 39 offering trays and 5 soul houses, the majority of which are currently displayed in the permanent galleries. This first publication presents a thorough study of all the offering trays. Soul houses will be addressed in a future paper. ${ }^{1}$

The Museo Egizio's collection of offering trays is particularly interesting and rich, since it includes a wide variety of well-preserved specimens and a sig- 
nificant number of related fragments, and the provenance and circumstances of acquisition are either well-known or can be reconstructed. Despite this, only a few of them (the best-preserved ones) have been discussed in the literature and, given earlier lack of interest towards this category of objects, their number and origin have been only partially established and understood.

In the present paper, all of the 39 pottery offering trays from the collection of the Museo Egizio are briefly described, analysed, and discussed. A considerable number of other trays from museum collections and archaeological excavations are also considered, allowing for comparisons, the identification of parallels, and the highlighting of apparent similarities and trends within the same site, area, or even region. While it would be difficult to properly summarise all the complex circumstances under which one of the largest collections of Egyptian antiquities in the world came into being, it should be kept in mind that a large part of the artefacts in the Museo Egizio (inventoried under the designation Catalogo, abbreviated C. or Cat.) was acquired with the purchase of the collection of Bernardino Drovetti, consul in Egypt. ${ }^{2}$ Another conspicuous group (inventoried under the designation Supplemento, abbreviated S. or Suppl.) came from the numerous campaigns of the Missione Archeologica Italiana (M.A.I.), directed by Ernesto Schiaparelli and his collaborators. ${ }^{3}$

There are also a number of objects which lost, for one reason or another, their original inventory numbers and were assigned new ones, prefixed "Provvisorio" (abbreviated P. or Provv.). Most of these objects are of uncertain provenance and their modalities of acquisition are unclear. ${ }^{4}$

The trays in the Museo Egizio can be divided into two groups according to provenance (Asyut, Gebelein) and a third group (unprovenanced) comprising all the remaining objects. The closest provenanced parallels will be used here as "anchors" to propose a likely geographical origin for the unprovenanced ones. Parallels will be searched for in the known corpus of trays from other museum collections and excavations. $^{5}$

In addition to the summary publication of the entire corpus of trays from the Museo Egizio, this article's main contribution is to provide a methodology for the typological study of the material and the identification of parallels for the reconstruction of provenances.

\subsection{Methodology}

The methodological standards followed for the analysis of the material first required a definition of the class of objects to which offering trays belong.

In the literature, ${ }^{6}$ offering trays are always treated as being in the same class as soul houses. While from a material point of view they are both made of clay, there is a slight difference between the two: an offering tray is a ceramic tray with representations of offerings on its surface; a soul house is also a ceramic offering tray with representations of offerings, but with the addition of a maquette, an architectural model, which constitutes the main focus of the tray and is its most distinguishable characteristic. The presence - or absence - of this maquette neatly distinguishes the two (Fig. 1).

Sub-classes encompass groups of offering trays with the same geographical provenance. It is useful to organise trays on the basis of provenance, as it has already been noted that shapes and decorations often outline regional and local trends. ${ }^{7}$ Starting from provenanced trays to distinguish types within different local corpora makes it easier to assess the significance and scope of the wealth of material with unstated or unknown provenance in museum collections.

Within the distinguished sub-classes, in the present

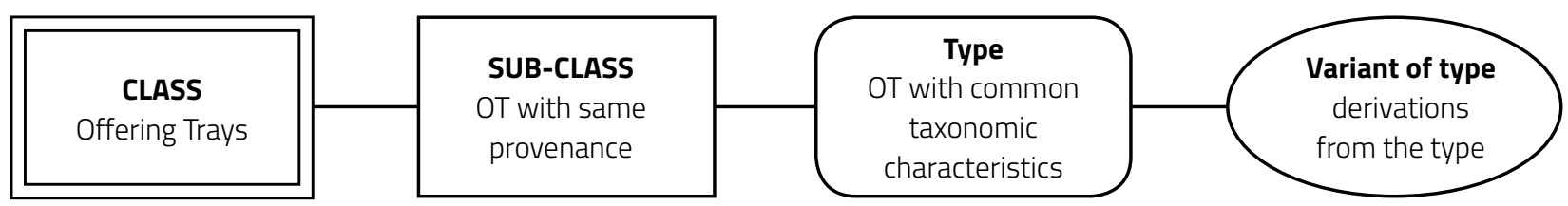

Fig. 1: Diagram summarising the typological criteria used in the present study. 
article types are determined on the basis of sets of common taxonomic features recurring in a relatively high number of objects. Such features include the shape of the tray, the colour of the paint applied onto its surface, the number of offerings depicted on it, ${ }^{8}$ the spatial arrangement of the surface, and other salient features.

Finally, variants are derivations from the type showing systematic differences, but including the type's dominant features. ${ }^{9}$

An unavoidable limit of the present research is that it does not adopt the Vienna System, considered today to be a standard method, ${ }^{10}$ for the description of the clay fabrics, due to the impossibility of cutting fresh breaks on the artefacts.

For the purpose of the investigation, a database was set up, a simplified version of which is visible in the several tables included in this article. For the Asyut material, shape, colour, spatial arrangement, quantity of offerings, as well as other features were taken into consideration. The same criteria were applied to the Gebelein corpus, except for spatial arrangement, since all the pieces share the same arrangement.

\section{Current state of research}

Offering trays have been discussed in a number of articles published in the course of the twentieth and twenty-first centuries, stimulated by the increasing quantity of material discovered in excavations all over Egypt. ${ }^{11}$ Actually, offering trays have been part of museum collections since the first half of the nineteenth century. ${ }^{12}$ Yet, interest among Egyptologists was never keen enough for the wealth of available material to be organised into comprehensive catalogues or monographs, most probably due to their anepigraphic nature. ${ }^{13}$ This has left the total number of trays in museum collections and excavations unquantified and the distinction between types in the same class of material never sufficiently clear. ${ }^{14}$ Such a quantification would be the first necessary step to understand the position of trays within the range of cultic and ritual activities. More recent times have seen an increase of articles and publications covering the subject in more or less homogeneous ways. ${ }^{15}$ Still, we are far from having quantified the material and we continue to work on different corpora and different collections, each of us applying their own method and terminology, often different from those of the others.

As regards the state of research on the subject, the most updated and complete articles on offering trays were written by A. Kilian, who published the material from the German-Egyptian excavations in the necropolis of Asyut. ${ }^{16}$ Her articles summarise - and clarify - the main interpretations of offering trays, and include general remarks about the materiality, decoration, placement, and use of trays, as well as adding to the corpus new material from recent excavations in Asyut.

\subsection{Origin and development}

Offering trays have been interpreted as directly derived from stone offering tables, and the difference in materials as a direct consequence of the economic background of the owners, clay constituting a cheaper alternative to stone. ${ }^{17}$ However, it should be noted that offering trays ceased to exist after the Middle Kingdom, while stone offering tables were used throughout Egyptian history. Furthermore, Killian has called attention to the completely anepigraphic nature of offering trays as opposed to the often inscribed tables, and highlighted the variety of shapes of trays as a main difference from the (almost) invariably rectangular shape of tables, and the much wider range of objects, images, and offerings depicted on stone tables compared to their clay "counterparts". ${ }^{18}$ Given these considerations, it would not be accurate to state that offering trays are directly and exclusively developed from offering tables.

An attempt to propose a theory of the development of offering trays was first made by Niwinski, who defined the process of formal change whereby the shape of the base gradually shifted from square to round as "décadence formelle" ${ }^{19}$ This theory has been strongly dismissed by Tooley, ${ }^{20}$ because the hypothesis is based on an incorrect dating of the material: Niwinski dates round trays later than square trays, but the opposite has been demonstrated by Slater, who dates the Dendera offering trays (predominantly of round and oval shapes) exclusively to the First Intermediate Period. ${ }^{21}$ Additionally, Tooley's research, which also takes in materials from other archaeological excavations, has shown that tray shapes depend on regional trends, ${ }^{22}$ with square trays being typi- 
cal of Middle Egypt and round trays of Upper Egypt. This concept will be shown to be of crucial relevance for the present research, since it has been theorised that base shape is one of the criteria to determine the provenance of a tray. ${ }^{23}$ This approach departs from the concept that no two offering trays can be identical: ${ }^{24}$ actually, many of them share common features, allowing for typological distinctions.

\subsection{Function and dating}

Offering trays are basins whose purpose and main function was the collection of liquid libations poured on them by the officiants of offering rituals. $^{25}$ The nature of the ritual is strictly related to the provision of nourishment, often represented by miniature model offerings present on the surface of trays. While trays mainly occur in tombs and funerary contexts, their discovery in other contexts such as settlements, Nubian fortresses and, in one case, temples, makes the picture more complex. ${ }^{26}$

Since the material is completely anepigraphic (except in one case $)^{27}$ and there is no mention whatsoever of trays in the corpus of ancient Egyptian literature, ${ }^{28}$ offering trays have always been dated on the basis of their archaeological context, when this was well documented and pottery was found with the trays. This has resulted in a late First Intermediate Period - early Middle Kingdom date, with the earliest attestations occurring in the necropolis of Balat. ${ }^{29}$ In only one case, a thermoluminescence analysis was carried out, on an offering tray by the Roemer und Pelizaeus Museum, but it yielded a chronological span covering almost 700 years and three phases of Egyptian history, and can thus be considered to be unsatisfactory for the definition of the material's chronological horizon. ${ }^{30}$

Offering trays seem to disappear ${ }^{31}$ in the late Twelfth or early Thirteenth Dynasty. ${ }^{32}$

\subsection{Future research}

It should be mentioned that the approach used in this work is experimental. Only further research on the subject will be able to shed more light on issues such as typological divisions and provenance. Moreover, some of the trays mentioned here have not been directly examined by the present author, but only seen in photographs. A future step would be to collect as much material as possible, in order to expand the range of specimens available for typological seriation, extending it to the whole corpus of known offering trays.

Performing a thorough data collection and establishing a potentially valid typology would be a pre-requisite for addressing other considerations, particularly socio-anthropological aspects, such as the rituals carried out on the trays, or semiotic aspects relating to the trays themselves and the modelled offerings applied onto them. Moreover, while the social environment behind the production of these objects has been treated only superficially, interesting insights could be gleaned from well-documented archaeological contexts. Questions regarding the producers, the social environment, the significance of the presence - or absence - of certain offerings, the relationship of the offering tray to the pictorial and literary corpus of the First Intermediate Period and the Middle Kingdom, the precise set of actions carried out during the rituals, are just some of the relevant questions that could be asked of the material.

The historical and artistic potential of this material has only been partially fulfilled. Its dissemination in the cultic sphere - measurable only after having quantified the number of trays found - could be analysed by relating it to other objects with the same functions (stone offering tables and soul houses), in an attempt to elucidate the stylistic and material relations underlying a social and regional context.

\section{Offering trays from Asyut}

The fourteen offering trays recovered by the Italian Archaeological Mission in Asyut and now held in the Museo Egizio were collected during several archaeological campaigns spanning from 1906 to 1913. The archaeological contexts of discovery are not specified in the available records, except in one case (S. 7979, see below). It is known that S. 8141 was found in 1906, and S. 9179 in 1907 or $1908 .^{33}$ S. 10647 and S. 10648 were found in 1910. The remaining nine trays were found during the archaeological missions from 1911 to $1913 .^{34}$

The trays recovered by Schiaparelli are comparable with the material excavated by Hogarth, Chassinat, ${ }^{35}$ Kamal, ${ }^{36}$ and more recently the German-Egyptian mission. All the Siutian trays published and made 
available in publications, reports, catalogues, and online databases were considered for the present study. The British Museum collection was studied through photographs available on the online catalogue. The trays recovered by the German-Egyptian mission were studied using published data in reports, articles, and publications.

The Siutian offering trays were all modelled in Nile clay. The predominant shape is quadrangular (60.71\%), with a protruding spout. Rectangular shapes (12.5\%) are attested, as well as two U-shaped trays (3.57 \%) and two oval ones (3.57\%). The rest are too fragmentary for the original shape to be recognised.

The sheer majority is painted over with a red-brown washing $(66.07 \%)$. The remaining trays are either whitewashed $(16.07 \%$ ) or unpainted (four specimens, $7.14 \%$ ), or their surface is too poorly pre- served to establish this.

A defining feature of many trays from Asyut is the presence of internal boundaries, small L-shaped inner edges that divide the surface. ${ }^{37}$ The separation of internal spaces on the surface appears to be inspired by contemporary stone offering tables. ${ }^{38}$ On the other hand, some trays from Asyut show no spatial divisions of any sort, thus making this a criterion for typological distinction. The presence, absence, or placement of the ox head is also a criterion for typological distinction, as the head appears on $80 \%$ of the trays from Asyut.

Combining all these criteria, the present author has developed a typological distinction into four types and five variants (Fig. 2).

The first type, Asyut Type I, comprises rectangular and U-shaped trays, with sunken parallel basins and

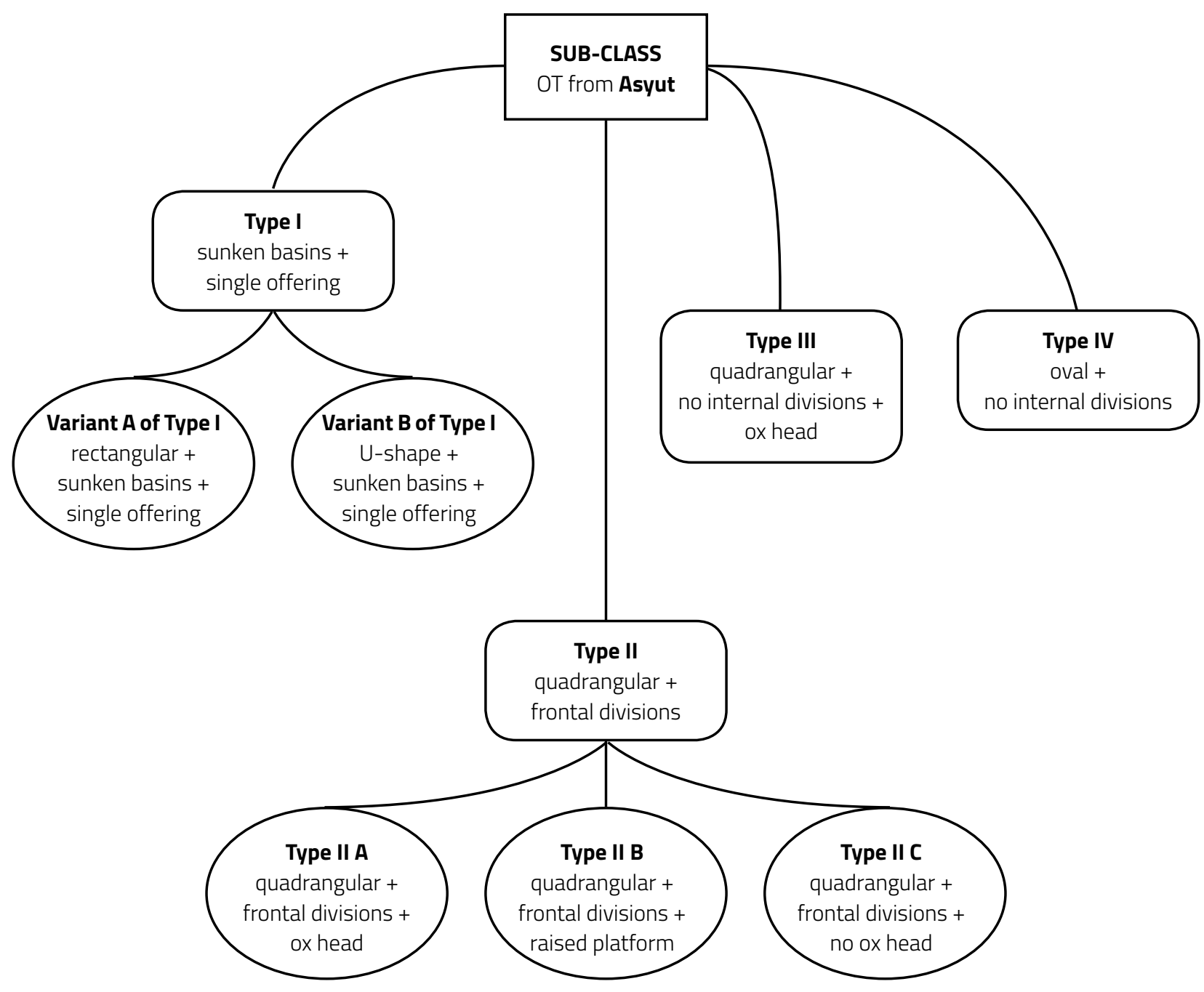

Fig. 2: Diagram summarising the types and variants discerned in the corpus of offering trays from Asyut. 


\begin{tabular}{|l|l|l|l|l|l|l|l|}
\hline Inv. no. & Shape & Paint & $\begin{array}{l}\text { Spatial } \\
\text { Arrangement }\end{array}$ & $\begin{array}{l}\text { Distinctive } \\
\text { feature }\end{array}$ & $\begin{array}{l}\text { Multiple } \\
\text { offerings }\end{array}$ & $\begin{array}{l}\text { Measurements cm } \\
\text { (H x W x D) }\end{array}$ & $\begin{array}{l}\text { State of } \\
\text { preservation }\end{array}$ \\
\hline S. 7979 & rectangular & red & $\begin{array}{l}\text { sunken } \\
\text { parallel } \\
\text { basins }\end{array}$ & $\begin{array}{l}\text { single } \\
\text { offering }\end{array}$ & no & $4.5 \times 19 \times 26.5$ & whole \\
\hline S. 14945 & rectangular & white & $\begin{array}{l}\text { sunken } \\
\text { parallel } \\
\text { basins }\end{array}$ & $\begin{array}{l}\text { single } \\
\text { offering }\end{array}$ & no & $5.5 \times 13.5 \times 22.5$ & whole \\
\hline EA 46611 & rectangular & red & $\begin{array}{l}\text { sunken } \\
\text { parallel } \\
\text { basins }\end{array}$ & $\begin{array}{l}\text { single } \\
\text { offering }\end{array}$ & no & $6.8 \times 22.7 \times 27.6$ & whole \\
\hline EA 46612 & rectangular & red & $\begin{array}{l}\text { sunken } \\
\text { parallel } \\
\text { basins }\end{array}$ & $\begin{array}{l}\text { single } \\
\text { offering }\end{array}$ & no & $5.5 \times 18 \times 23$ & whole \\
\hline
\end{tabular}

Table 1: Asyut Type I Variant A.

a single raised elongated offering, which could well represent a loaf of bread or a Htp sign, as is the case in contemporary offering tables. ${ }^{39}$ Type I Variant A includes at least four specimens, presently held in the Museo Egizio and the British Museum (EA) (Table 1$):^{40}$

- S. 7979 (Fig. 3) is roughly modelled, with two sub-elliptical depressions between which lies a modelled raised offering. The depressions are connected to each other through a narrow channel incised with a thin tool, which runs below the tip of the raised offering. One of the depressions has a hole for the pouring of liquids. A direct parallel for this tray, albeit of better quality, is EA 46612. S. 7979 is the only Turin offering tray whose archaeological context is known, having been recovered by Schiaparelli's mission in Tomb $2 .{ }^{41}$ The context of the tomb was disturbed and only

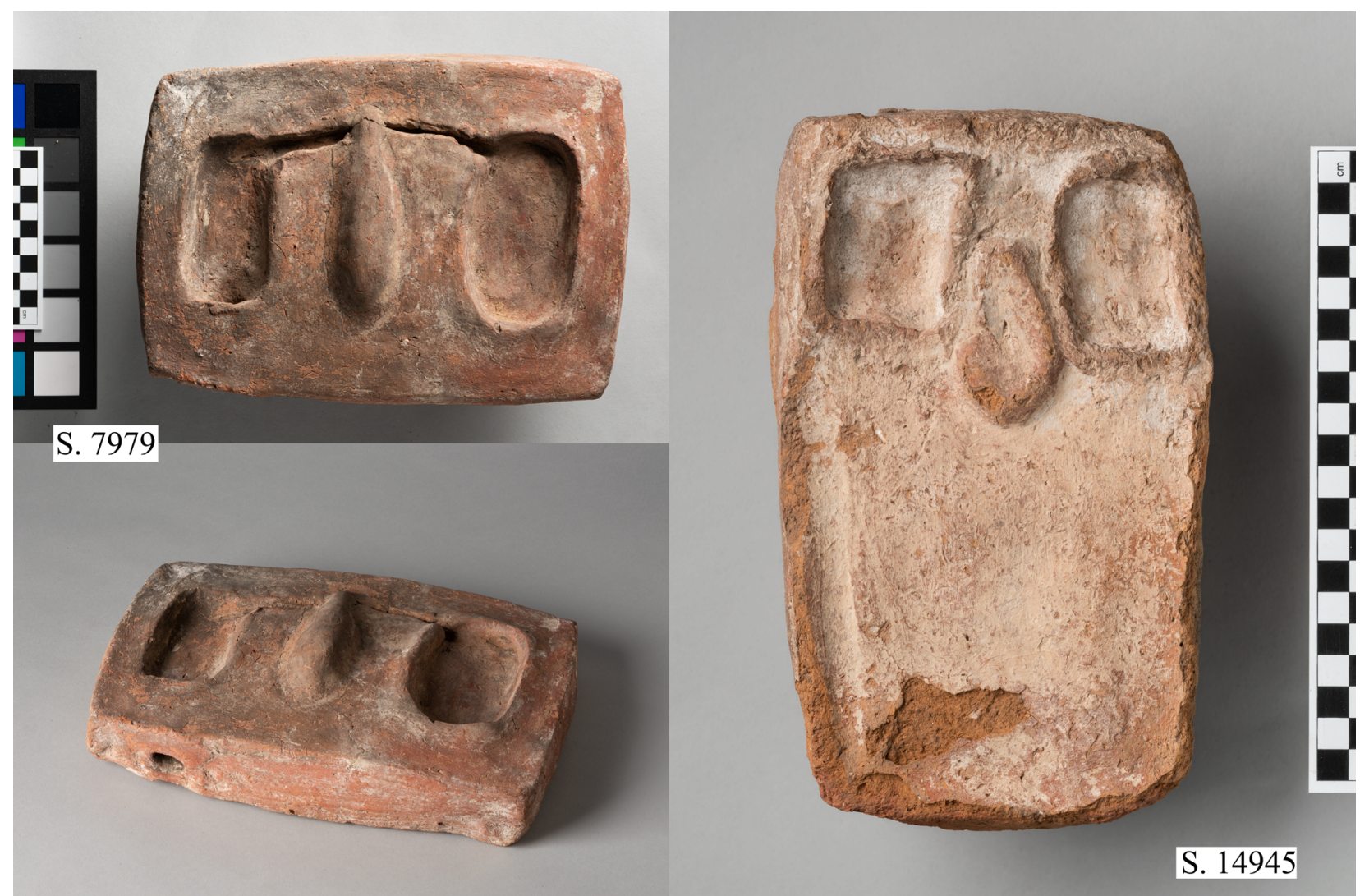

Fig. 3: S. 7979 and S. 14945. Photos by Nicola dell'Aquila and Federico Taverni/Museo Egizio. 


\begin{tabular}{|l|l|l|l|l|l|l|l|}
\hline Inv. no. & Shape & Paint & $\begin{array}{l}\text { Spatial } \\
\text { Arrangement }\end{array}$ & $\begin{array}{l}\text { Distinctive } \\
\text { feature }\end{array}$ & $\begin{array}{l}\text { Multiple } \\
\text { offerings }\end{array}$ & $\begin{array}{l}\text { Measurements cm } \\
\text { (H x W x D) }\end{array}$ & $\begin{array}{l}\text { State of } \\
\text { preservation }\end{array}$ \\
\hline OT1 & rectangular & white & $\begin{array}{l}\text { sunken } \\
\text { parallel } \\
\text { basins }\end{array}$ & $?$ & $?$ & $?$ & fragmentary \\
\hline OT14 & rectangular & $?$ & $\begin{array}{l}\text { sunken } \\
\text { basins }\end{array}$ & $?$ & $?$ & $?$ & fragmentary \\
\hline OT27 & rectangular & white & $\begin{array}{l}\text { sunken } \\
\text { parallel } \\
\text { basins }\end{array}$ & $?$ & $?$ & $?$ & fragmentary \\
\hline OT38 & $?$ & $?$ & $\begin{array}{l}\text { sunken } \\
\text { parallel } \\
\text { basins }\end{array}$ & $?$ & $?$ & $?$ & fragmentary \\
\hline OT44 & rectangular & white & $?$ & $?$ & $?$ & $?$ & fragmentary \\
\hline
\end{tabular}

Table 2: fragments of OT recovered in Asyut by the German-Egyptian mission, possibly Asyut Type I Variant A.

a few of the objects from the burial assemblage were recovered: a pottery sherd of a vessel (shoulder + rim, Nile clay, red slip, S. 7975 [sic]); three headrests (S. 7975/1,2,3); two jars (S. 7976 with an ovaloid body and vertical band-shaped rim; S. 7977 with a sub-cylindrical body and an extroverted rim); and an unfired stopper, S. 7980. A date can be proposed for Tomb 2 thanks to the material found inside it, particularly the jars. The ovaloid jar S. 7976 has direct parallels datable to the mid-Eleventh-early-Twelfth Dynasties. ${ }^{42}$ Jar S. 7977 finds a direct parallel in pottery excavated in Asyut by the German-Egyptian mission and dated to the Eleventh Dynasty (Mentuhotep II). ${ }^{43}$ The three headrests also point to a date at the transition from the First Intermediate Period to the Middle Kingdom, since their shapes are attested both in Old and Middle Kingdom contexts. ${ }^{44} \mathrm{~A}$ slightly earlier date cannot be ruled out, as P. Del Vesco dates similar material from the same site to the First Intermediate Period only. ${ }^{45}$
- S. 14945: (Fig. 3) this second tray is the only whitewashed specimen from Asyut in the Museo Egizio. The two quadrangular depressions, encircled by low rims, are separated by a drop-shaped raised offering. A single channel was traced on the left side of the tray by finger impression. The closest parallel for this specimen is EA 46611.

Some fragments recovered in Asyut by the German-Egyptian mission ${ }^{46}$ may belong to this type, but they are too poorly preserved for this to be sure (Table 2).

Type I Variant B is comprised of two U-shaped offering trays ${ }^{47}$ with basins and a single raised offering (Table 3).

- S.14943 (Fig. 4) is more difficult to interpret since its surface features are less ascertainable due to erosion. It is a U-shaped offering tray, with two quadrangular depressions in the central part of the tray and a bigger depression in the front.

All the offering trays of Asyut Type I share common

\begin{tabular}{|l|l|l|l|l|l|l|l|}
\hline Inv. no. & Shape & Paint & $\begin{array}{l}\text { Spatial } \\
\text { Arrangement }\end{array}$ & $\begin{array}{l}\text { Distinctive } \\
\text { feature }\end{array}$ & $\begin{array}{l}\text { Multiple } \\
\text { offerings }\end{array}$ & $\begin{array}{l}\text { Measurements cm } \\
\text { (H x W x D) }\end{array}$ & $\begin{array}{l}\text { State of } \\
\text { preservation }\end{array}$ \\
\hline S. 14943 & U-shape & red & $\begin{array}{l}\text { sunken } \\
\text { parallel } \\
\text { basins }\end{array}$ & $\begin{array}{l}\text { single } \\
\text { offering }\end{array}$ & no & $5 \times 21.5 \times 28$ & whole \\
\hline EA 46610 & U-shape & red & $\begin{array}{l}\text { sunken } \\
\text { parallel } \\
\text { basins }\end{array}$ & $\begin{array}{l}\text { single } \\
\text { offering }\end{array}$ & no & $5.5 \times 21 \times 27.2$ & whole \\
\hline
\end{tabular}

Table 3: Asyut Type I Variant B. 


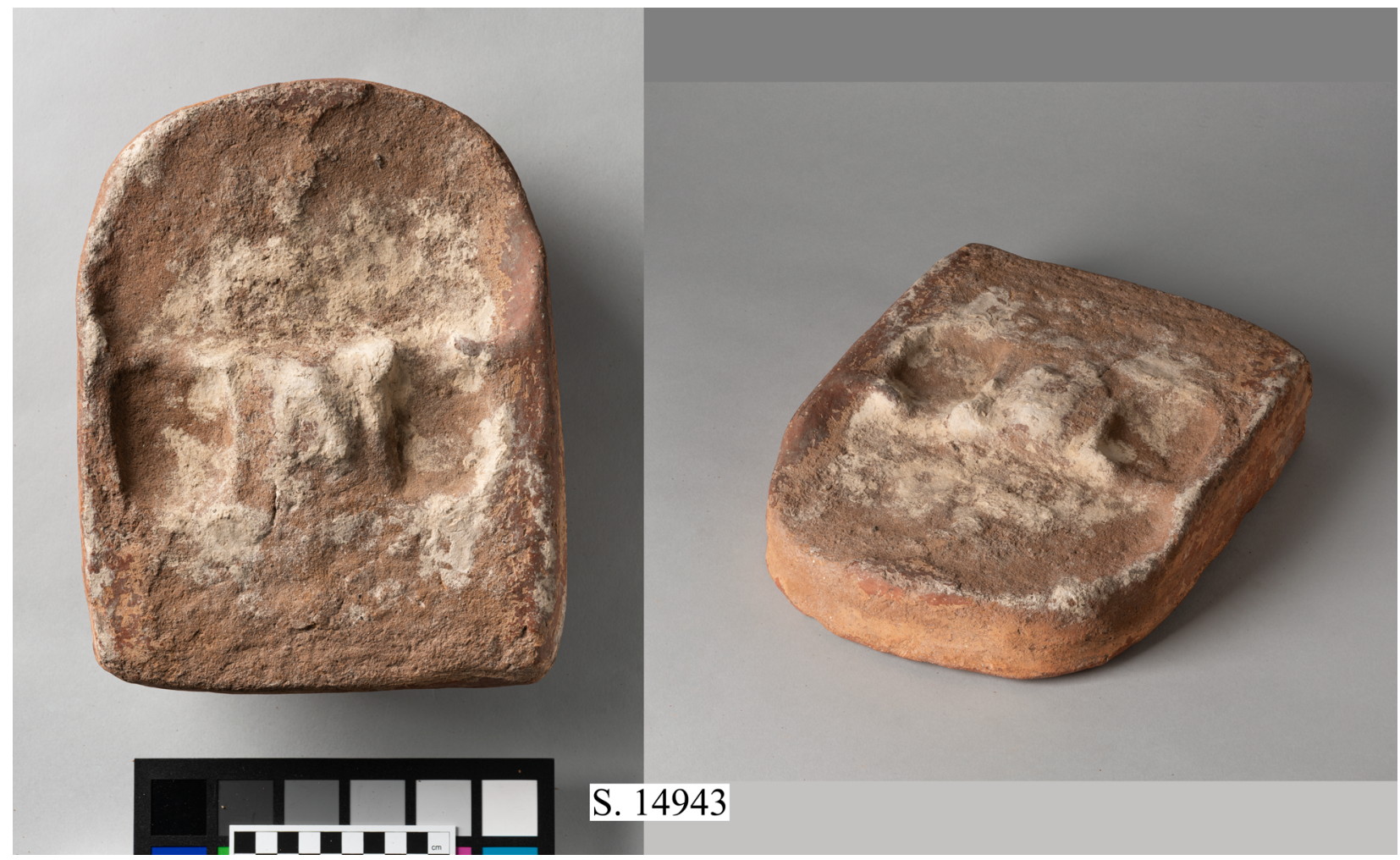

Fig. 4: S. 14943. Photos by Nicola dell'Aquila and Federico Taverni/Museo Egizio.

formal features with three stone offering tables recovered in 1905 by Schiaparelli in Asyut, ${ }^{48}$ which are rectangular in form, have parallel square basins, and a rudimental single sculpted $h t p$ sign.

Asyut Type II includes quadrangular trays ${ }^{49}$ with L-shaped or C-shaped internal divisions creating two spaces, one where modelled offerings are laid and one from which the spout departs. In Type II Variant A (Table 4), an ox head is always depicted. The tray recovered by Kamal certainly falls under this type, but its dimensions and present whereabouts are unknown.

- S. 10647 (Fig. 5): The shape of this tray is very irregular. It is difficult to read the features on the internal surface due to the state of preservation of the object, but some details are still discernible. Traces of red paint can be made out on the rim and on the external surface. The ox head against the back rim is without horns and has a very elongated snout and 5 small incisions on the top. The eyes, ears, and nostrils are not depicted. The entire surface of the tray is divided into 5 sections, with very long frontal delimitations that bend and extend to the very large spout in the front of the tray. A circular depression ( $7.4 \mathrm{~cm}$ in diameter) is visible on the left side of the object.

- S. 10648 (Fig. 5): The internal and external surfaces were painted red, but the pigment is mainly preserved inside the tray, while outside it is barely visible due to the poor state of preservation of the piece. The ox head, which has very long horns, is at the centre of the rear rim. The surface shows offerings (ox leg, bread loaves, ox ribs, and four distinctive quadrangular objects I have been unable to identify) in the centre, encircled by channels that run towards the protruding spout. The top of the very thin high rim was flattened on the sides but not at the back, the spout, or the front. There are internal L-shaped delimitations, in which circular depressions are visible on the front of the tray.

- S. 14848 (?) (Fig. 5): This tray, which has a slightly unusual shape, is almost completely preserved. At the back, an ox head with long horns lies against the rim. In front of it, offerings are scattered around, among which an ox leg, two bread loaves, ox ribs and probably a $h s$ vase can be identified. The dividing walls on the front are C-shaped and the front rim of the tray follows the shape of the dividing walls.

- S. 14940 (Fig. 5): Red-washed on the inside 


\begin{tabular}{|l|l|l|l|l|l|l|l|}
\hline Inv. no. & Shape & Paint & $\begin{array}{l}\text { Spatial } \\
\text { Arrangement }\end{array}$ & $\begin{array}{l}\text { Distinctive } \\
\text { feature }\end{array}$ & $\begin{array}{l}\text { Multiple } \\
\text { offerings }\end{array}$ & $\begin{array}{l}\text { Measurements cm } \\
\text { (H x W x D) }\end{array}$ & $\begin{array}{l}\text { State of } \\
\text { preservation }\end{array}$ \\
\hline S. 10647 & quadrangular & red & $\begin{array}{l}\text { frontal } \\
\text { divisions }\end{array}$ & ox head & many & $5.5 \times 20 \times 26$ & whole \\
\hline S. 10648 & quadrangular & red & $\begin{array}{l}\text { frontal } \\
\text { divisions }\end{array}$ & ox head & many & $4.5 \times 23.5 \times 31$ & whole \\
\hline $\begin{array}{l}\text { S. } 14848 \\
\text { (?) }\end{array}$ & quadrangular & no & $\begin{array}{l}\text { frontal } \\
\text { divisions }\end{array}$ & ox head & many & $5 \times 26 \times 31$ & whole \\
\hline $\begin{array}{l}\text { S. } 14940 \\
\text { S. } 14941\end{array}$ & quadrangular & red & $\begin{array}{l}\text { frontal } \\
\text { divisions }\end{array}$ & ox head & many & $5.5 \times 20 \times 31$ & whole \\
\hline EA 46608 & quadrangular & red & $\begin{array}{l}\text { frontal } \\
\text { divisions } \\
\text { frontal } \\
\text { divisions }\end{array}$ & ox head & many & $4 \times 23 \times 27.3$ & whole \\
\hline EA 46614 & quadrangular & red & $\begin{array}{l}\text { frontal } \\
\text { divisions }\end{array}$ & ox head & many & $4.1 \times 24 \times 31.6$ & whole \\
\hline $\begin{array}{l}\text { Sporadic } \\
\text { find } \\
\text { (Kamal, } \\
\text { ASAE 16) }\end{array}$ & quadrangular & $\begin{array}{l}\text { frontal } \\
\text { division }\end{array}$ & $\begin{array}{l}\text { frontal } \\
\text { divisions }\end{array}$ & ox head & many & $?$ & whole \\
\hline
\end{tabular}

Table 4: Asyut Type II Variant A.

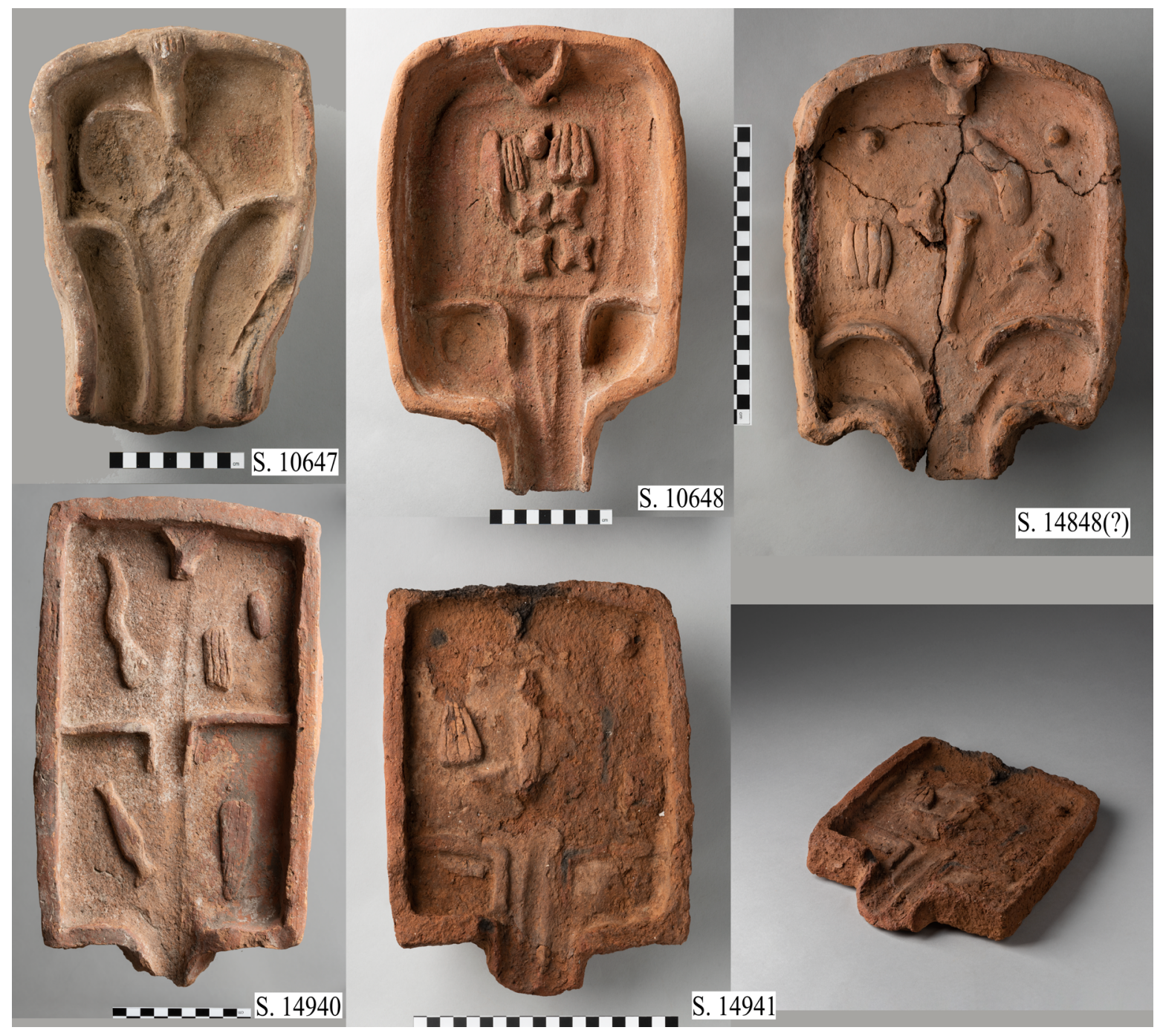

Fig. 5: S. 10647, S. 10648, S. 14848 (?), S. 14940, and S. 14941. Photos by Nicola dell'Aquila and Federico Taverni/Museo Egizio. 
and outside surfaces, the latter of which were smoothed. The top of the rim is flattened. The dividing walls and offerings were modelled separately and subsequently applied and smoothed down. The offerings include an ox leg, bread loaves, a $h s$ vase, and ribs.

- S. 14941 (Fig. 5): Very eroded, probably due to inadequate firing, among other things. Very few offerings are preserved and recognisable: a rib, probably a $h s$ vase, and the ox head, whose horns only remain. The two dividing walls on the front are L-shaped and a channel runs towards the protruding spout. No traces of paint are visible.
Type II Variant B is characterised by quadrangular trays, ${ }^{50}$ with frontal divisions and raised platforms at the back of the tray, on top of which offerings are sometimes displayed (Table 5).

- S. 9179 (Fig. 6) has a single platform, with an ox leg and a round loaf of bread represented on it.

- S. 14944 (Fig. 6) has two platforms, one with an ox head, the other with an ox leg and a round loaf of bread.

The most direct parallels can be found in an offering tray recovered in Dendera by Petrie ${ }^{51}$ and an unprovenanced offering tray in the Liverpool Museum, 1973.1.362. ${ }^{52}$

\begin{tabular}{|l|l|l|l|l|l|l|l|}
\hline Inv. no. & Shape & Paint & $\begin{array}{l}\text { Spatial } \\
\text { Arrangement }\end{array}$ & $\begin{array}{l}\text { Distinctive } \\
\text { feature }\end{array}$ & $\begin{array}{l}\text { Multiple } \\
\text { offerings }\end{array}$ & $\begin{array}{l}\text { Measurements cm } \\
\text { (H x W x D) }\end{array}$ & $\begin{array}{l}\text { State of } \\
\text { preservation }\end{array}$ \\
\hline S. 9179 & quadrangular & red & $\begin{array}{l}\text { frontal } \\
\text { divisions }\end{array}$ & $\begin{array}{l}\text { raised } \\
\text { platform }\end{array}$ & few & $4.6 \times 23 \times 29.5$ & whole \\
\hline S. 14944 & quadrangular & red & $\begin{array}{l}\text { frontal } \\
\text { divisions }\end{array}$ & $\begin{array}{l}\text { raised } \\
\text { platform }\end{array}$ & few & $4 \times 19.5 \times 21$ & whole \\
\hline EA 46617 & quadrangular & red & $\begin{array}{l}\text { frontal } \\
\text { divisions }\end{array}$ & $\begin{array}{l}\text { raised } \\
\text { platform }\end{array}$ & no & $4.2 \times 21 \times 22.2$ & whole \\
\hline
\end{tabular}

Table 5: Asyut Type II Variant B.

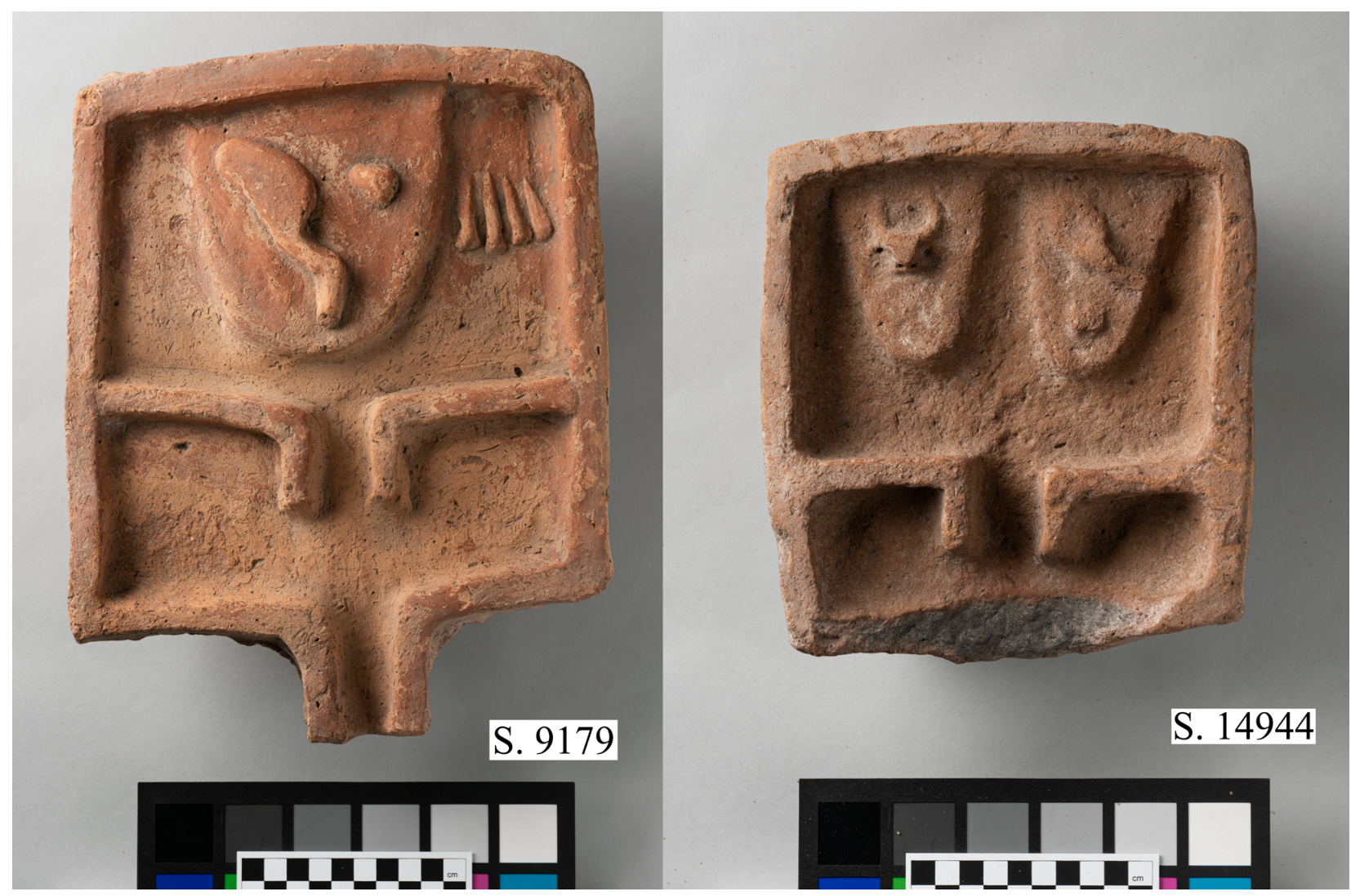

Fig. 6: S. 9179 and S. 14944. Photos by Nicola dell'Aquila and Federico Taverni/Museo Egizio. 


\begin{tabular}{|l|l|l|l|l|l|l|l|}
\hline Inv. no. & Shape & Paint & $\begin{array}{l}\text { Spatial } \\
\text { Arrangement }\end{array}$ & $\begin{array}{l}\text { Distinctive } \\
\text { feature }\end{array}$ & $\begin{array}{l}\text { Multiple } \\
\text { offerings }\end{array}$ & $\begin{array}{l}\text { Measurements cm } \\
\text { (H x W x D) }\end{array}$ & $\begin{array}{l}\text { State of } \\
\text { preservation }\end{array}$ \\
\hline P. 5537 & quadrangular & no & $\begin{array}{l}\text { frontal } \\
\text { divisions }\end{array}$ & ox head & no & $3.7 \times 20.5 \times 25.5$ & whole \\
\hline S. 14946 & quadrangular & red & $\begin{array}{l}\text { frontal } \\
\text { divisions }\end{array}$ & none & many & $5 \times 23.5 \times 28.5$ & whole \\
\hline EA 46607 & quadrangular & red & $\begin{array}{l}\text { frontal } \\
\text { divisions }\end{array}$ & ox head & many & $4.8 \times 24 \times 31.8$ & whole \\
\hline EA 46615 & quadrangular & red & $\begin{array}{l}\text { frontal } \\
\text { divisions }\end{array}$ & ox head & many & $4.5 \times 22 \times 29$ & fragmentary \\
\hline
\end{tabular}

Table 6: Asyut Type II Variant C.

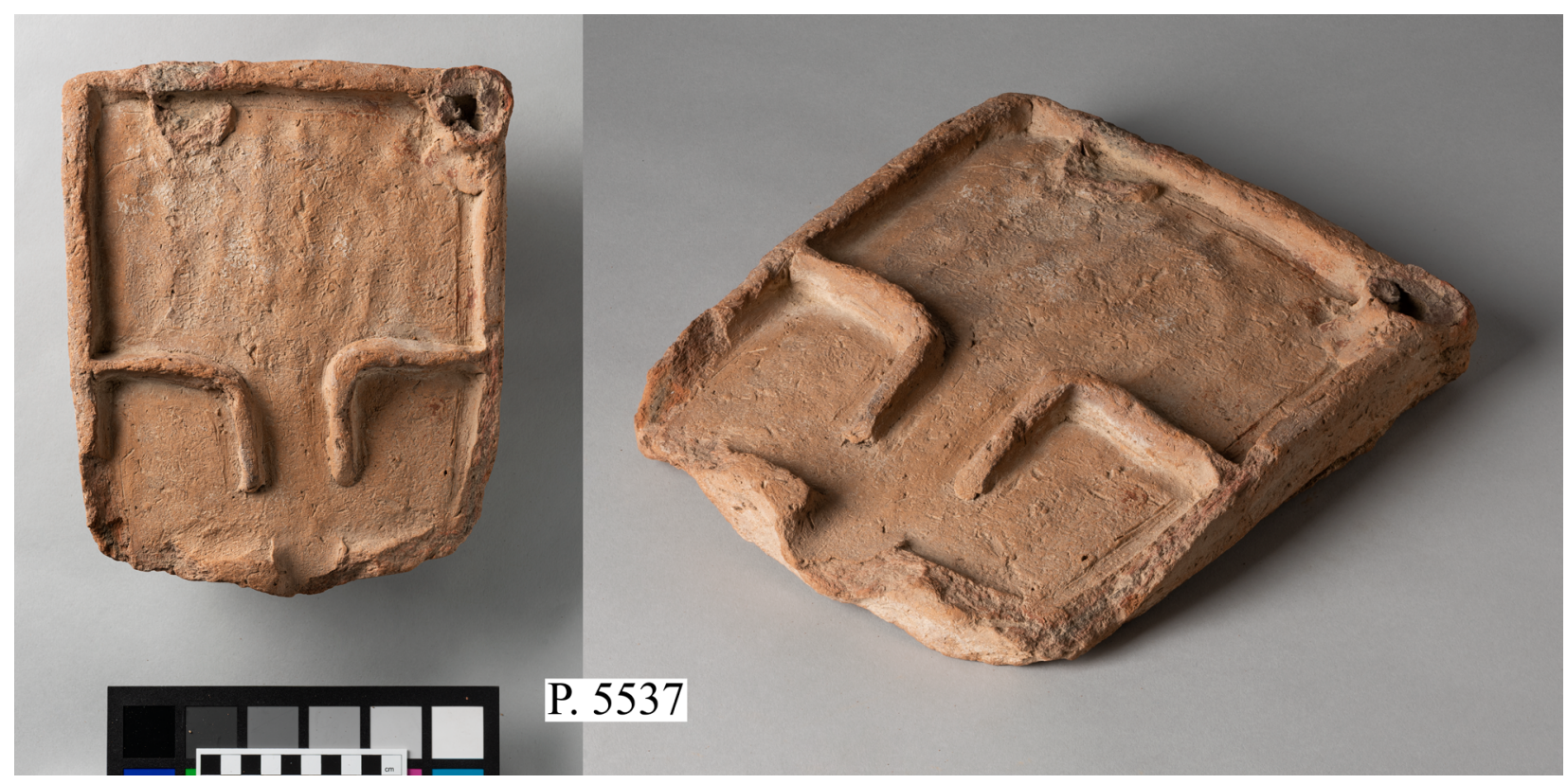

Fig. 7: P. 5537. Photo by Nicola dell'Aquila and Federico Taverni/Museo Egizio.

Type II Variant $\mathbf{C}$ (Table 6) is characterised by trays of quadrangular shape, ${ }^{53}$ with frontal divisions but without the ox head at the centre of the tray. The ox head is, instead, either decentred (P. 5537, S. 46607, S. 46615) or completely absent (S. 14946).

- P. 5537 (Fig. 7): this offering tray most certainly comes from Asyut, despite its provisional number. Its surface was red-washed and carefully smoothed. The offerings are almost lost, except for an ox head (only a trace of which is now visible) and a modelled vessel on the right corner of the tray, applied over the rim. The frontal delimitations have a smooth L-shape.

- S. 14946 (Fig. 8): The offerings were modelled separately, some of them smoothed with care, others not. Among the offerings, which are all rather crudely rendered, one is a series of four squares.
Despite its difficult interpretation, parallels can be found in soul houses found in Buhen. ${ }^{54}$ The dividing walls are L-shaped, with a sharp angle. The external rim was smoothed and flattened. Traces of red paint are still visible around the rim. On the left back side, a depression is encircled by a low wall. The bottom surface shows that the object was modelled on a very even surface. Interestingly, the bottom was red-washed.

Fragments probably belonging to Asyut Type II are listed below, ${ }^{55}$ but their fragmentary state makes it impossible to conclusively assign them to this type (Table 7).

Asyut Type III (Table 8) comprises trays of quadrangular shape, sometimes roughly modelled, with a small frontal spout. ${ }^{56}$ They always depict an ox head 


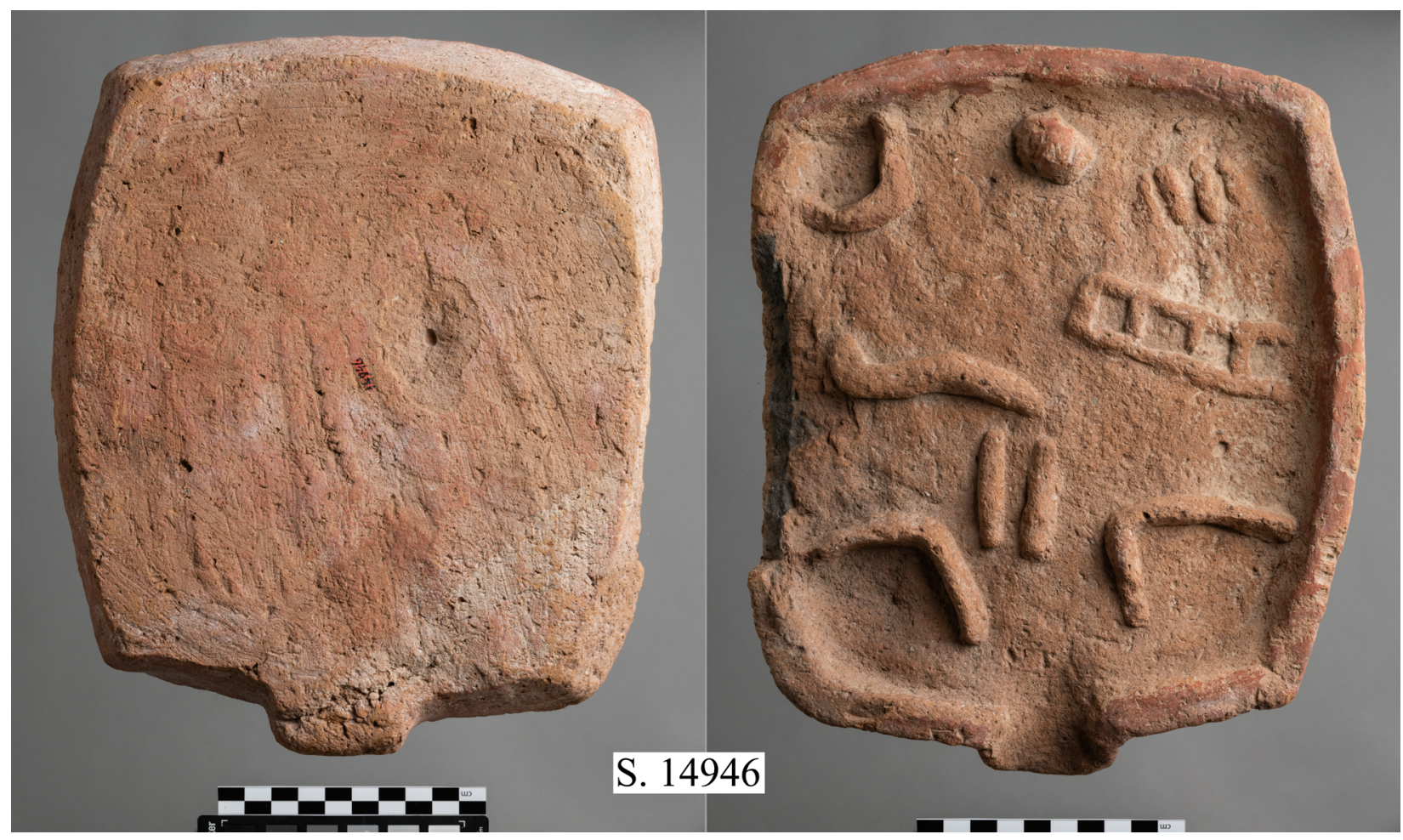

Fig. 8: S. 14946. Photo by Nicola dell'Aquila and Federico Taverni/Museo Egizio.

\begin{tabular}{|l|l|l|l|l|l|l|l|}
\hline Inv. no. & Shape & Paint & $\begin{array}{l}\text { Spatial } \\
\text { Arrangement }\end{array}$ & $\begin{array}{l}\text { Distinctive } \\
\text { feature }\end{array}$ & $\begin{array}{l}\text { Multiple } \\
\text { offerings }\end{array}$ & $\begin{array}{l}\text { Measurements cm } \\
\text { (H x W x D) }\end{array}$ & $\begin{array}{l}\text { State of } \\
\text { preservation }\end{array}$ \\
\hline $\begin{array}{l}\text { S. 14949 } \\
\text { (Fig. 9) }\end{array}$ & quadrangular & red & $\begin{array}{l}\text { frontal } \\
\text { divisions }\end{array}$ & $?$ & $?$ & $4.5 \times 9 \times 14$ & fragmentary \\
\hline OT18 & quadrangular & red & $\begin{array}{l}\text { frontal } \\
\text { divisions }\end{array}$ & $?$ & $?$ & $4.3 \times 10 \times 12.1$ & fragmentary \\
\hline OT22+0T29 & quadrangular & red & $?$ & ox head & $?$ & $?$ & fragmentary \\
\hline OT24 & quadrangular & $?$ & $\begin{array}{l}\text { frontal } \\
\text { divisions }\end{array}$ & $?$ & $?$ & $3.7 \times 15.6 \times 11.2$ & fragmentary \\
\hline
\end{tabular}

Table 7: Fragments of offering trays probably belonging to Asyut Type II.

\begin{tabular}{|l|l|l|l|l|l|l|l|}
\hline Inv. no. & Shape & Paint & $\begin{array}{l}\text { Spatial } \\
\text { Arrangement }\end{array}$ & $\begin{array}{l}\text { Distinctive } \\
\text { feature }\end{array}$ & $\begin{array}{l}\text { Multiple } \\
\text { offerings }\end{array}$ & $\begin{array}{l}\text { Measurements cm } \\
\text { (H x W x D) }\end{array}$ & $\begin{array}{l}\text { State of } \\
\text { preservation }\end{array}$ \\
\hline S. 8141 & quadrangular & no & $\begin{array}{l}\text { no internal } \\
\text { divisions }\end{array}$ & ox head & many & $3.8 \times 19.5 \times 21$ & whole \\
\hline EA 46609 & quadrangular & red & $\begin{array}{l}\text { no internal } \\
\text { divisions }\end{array}$ & ox head & many & $4.5 \times 21 \times 26.6$ & whole \\
\hline EA 46613 & quadrangular & white & $\begin{array}{l}\text { no internal } \\
\text { divisions }\end{array}$ & ox head & many & $8.2 \times 28 \times 31.4$ & whole \\
\hline EA 46616 & quadrangular & painted & $\begin{array}{l}\text { no internal } \\
\text { divisions }\end{array}$ & ox head & many & $4.6 \times 27 \times 35.4$ & almost whole \\
\hline EA 46618 & quadrangular & red & $\begin{array}{l}\text { no internal } \\
\text { divisions }\end{array}$ & ox head & many & $3 \times 11 \times 21$ & fragmentary \\
\hline EA 46619 & quadrangular & red & $\begin{array}{l}\text { no internal } \\
\text { divisions }\end{array}$ & ox head & many & $4.5 \times 14.5 \times 26$ & fragmentary \\
\hline EA 47372 & quadrangular & red & $\begin{array}{l}\text { no internal } \\
\text { divisions }\end{array}$ & ox head & many & $6 \times 22 \times 29.5$ & fragmentary \\
\hline
\end{tabular}

Table 8: Asyut Type III. 
at the centre of the back rim of the tray. There are no internal divisions on the surface of the tray. The offerings are arranged at the centre of the tray, be-

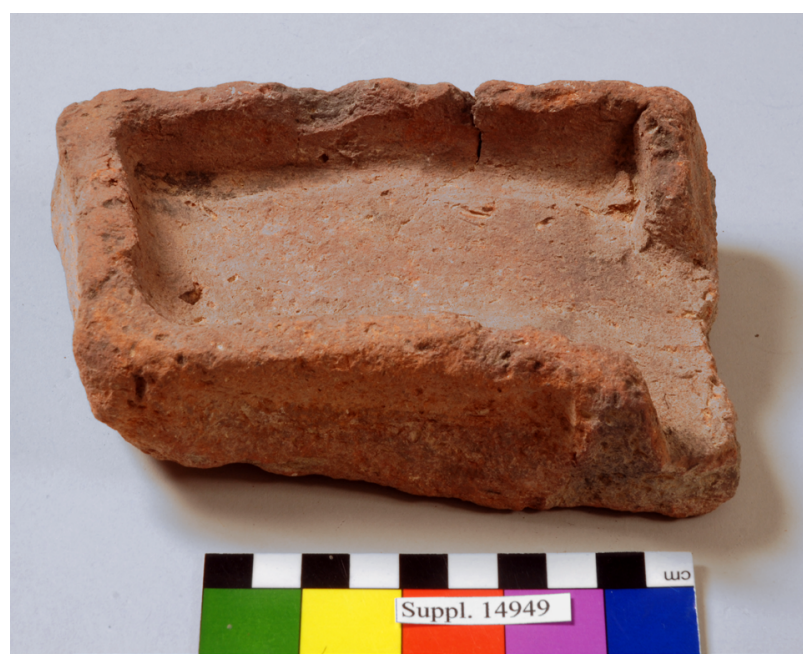

Fig. 9: S. 14949. Photo by Nicola dell'Aquila and Federico Taverni/Museo Egizio. tween the ox head and the spout.

The only specimen from the Museo Egizio belonging to this category is $\mathbf{S . ~} \mathbf{8 1 4 1}$ (Fig. 10), which finds its most direct parallel in a tray from the British Museum, EA $46616 .{ }^{57}$ They both have an irregular quadrangular shape, a small frontal spout, and offerings similarly displayed on the surface of the tray. Parallels from other sites include two trays recovered by Petrie at Kahun. ${ }^{58}$

Asyut Type IV comprises two specimens of oval shape, ${ }^{59}$ without internal divisions, but too fragmentary to ascertain the presence of the ox head at the rear of the tray (Table 9).

Other trays ${ }^{60}$ are too fragmentary to fall in any of the proposed typological groupings. I nonetheless include a table (Table 10). At least three trays from the Egyptian Museum in Cairo ${ }^{61}$ are pending proper

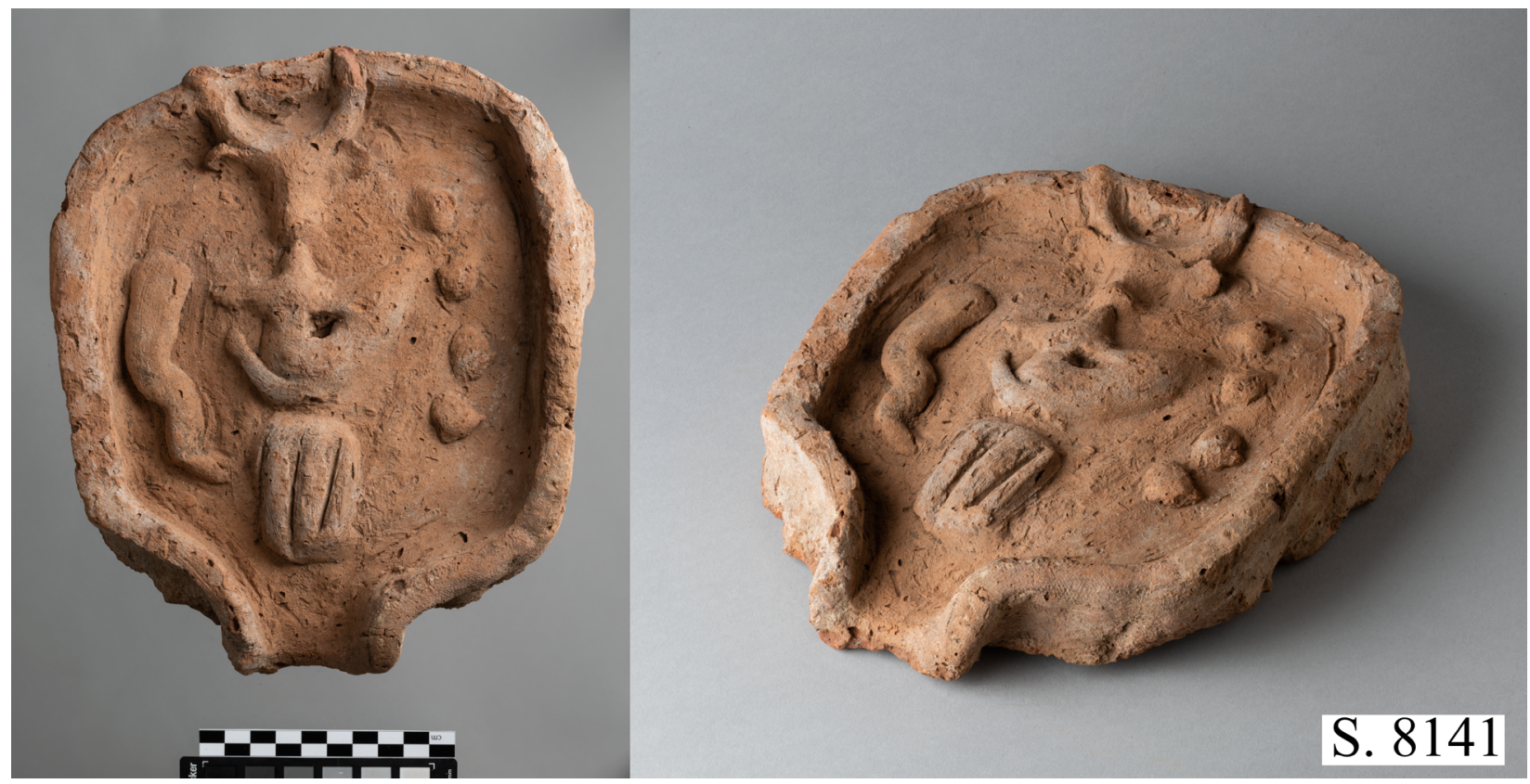

Fig. 10: S. 8141. Photos by Nicola dell'Aquila and Federico Taverni/Museo Egizio.

\begin{tabular}{|l|l|l|l|l|l|l|l|}
\hline Inv. no. & Shape & Paint & $\begin{array}{l}\text { Spatial } \\
\text { Arrangement }\end{array}$ & $\begin{array}{l}\text { Distinctive } \\
\text { feature }\end{array}$ & $\begin{array}{l}\text { Multiple } \\
\text { offerings }\end{array}$ & $\begin{array}{l}\text { Measurements cm } \\
\text { (H x W x D) }\end{array}$ & $\begin{array}{l}\text { State of } \\
\text { preservation }\end{array}$ \\
\hline $\begin{array}{l}\text { OT3+OT16+ } \\
\text { OT25+OT33+ } \\
\text { OT34 }\end{array}$ & oval & red & $\begin{array}{l}\text { no internal } \\
\text { divisions }\end{array}$ & $?$ & many & $?$ & fragmentary \\
\hline $\begin{array}{l}\text { OT10+OT17+ } \\
\text { OT21 }\end{array}$ & oval & red & $\begin{array}{l}\text { no internal } \\
\text { divisions }\end{array}$ & $?$ & $?$ & $?$ & fragmentary \\
\hline
\end{tabular}

Table 9: Asyut Type IV. 


\begin{tabular}{|c|c|c|c|c|c|c|c|}
\hline Inv. no. & Shape & Paint & $\begin{array}{l}\text { Spatial } \\
\text { Arrangement }\end{array}$ & $\begin{array}{l}\text { Distinctive } \\
\text { feature }\end{array}$ & $\begin{array}{l}\text { Multiple } \\
\text { offerings }\end{array}$ & $\begin{array}{l}\text { Measurements cm } \\
(\mathrm{H} \times \mathrm{W} \times \mathrm{D})\end{array}$ & $\begin{array}{l}\text { State of } \\
\text { preservation }\end{array}$ \\
\hline EA 46620 & quadrangular & red & $?$ & $?$ & many & $5.3 \times 16 \times 22$ & fragmentary \\
\hline EA 46621 & $?$ & red & $?$ & $?$ & $?$ & $4.5 \times 10.5 \times 19.2$ & fragmentary \\
\hline EA 46622 & quadrangular & red & $?$ & $?$ & $?$ & $2.8 \times 9.5 \times 15.1$ & fragmentary \\
\hline $\begin{array}{l}\text { OT4+OT13+ } \\
\text { OT35 }\end{array}$ & quadrangular & white & $?$ & $?$ & $?$ & $?$ & fragmentary \\
\hline OT5+OT9 & $?$ & white & $?$ & $?$ & $?$ & $?$ & fragmentary \\
\hline OT6 & quadrangular & $?$ & $?$ & ox head & $?$ & $3.4 \times 15 \times 15.7$ & fragmentary \\
\hline OT7+OT20 & $?$ & red & $?$ & $?$ & $?$ & $?$ & fragmentary \\
\hline OT8 & quadrangular & red & $?$ & $?$ & $?$ & $3.9 \times 8.9 \times 17.4$ & fragmentary \\
\hline $\begin{array}{l}\text { OT12+0T30+ } \\
\text { OT31+0T32 }\end{array}$ & quadrangular & $?$ & $?$ & $?$ & $?$ & $?$ & fragmentary \\
\hline OT15 & $?$ & red & $?$ & $?$ & $?$ & $6.7 \times 8.8$ & fragmentary \\
\hline OT19 & $?$ & red & $?$ & $?$ & $?$ & $3.1 \times 6.7 \times 10$ & fragmentary \\
\hline OT23 & $?$ & white & $?$ & $?$ & $?$ & $4.4 \times 15.5 \times 8.6$ & fragmentary \\
\hline ОТ36 & quadrangular & red & $?$ & $?$ & $?$ & $10 \times 9.5$ & fragmentary \\
\hline OT56 & quadrangular & red & $?$ & $?$ & $?$ & $4.1 \times 12.5 \times 9.8$ & fragmentary \\
\hline OT58 & quadrangular & red & $?$ & $?$ & $?$ & $4.4 \times 3.4 \times 3.3$ & fragmentary \\
\hline OT26 & quadrangular & white & $?$ & $?$ & many & $?$ & fragmentary \\
\hline OT41 & quadrangular & red & $?$ & $?$ & $?$ & $?$ & fragmentary \\
\hline OT40 & $?$ & $?$ & $\begin{array}{l}\text { frontal } \\
\text { divisions }\end{array}$ & $?$ & $?$ & $?$ & fragmentary \\
\hline
\end{tabular}

Table 10: Trays that are too fragmentary to fall in any of the proposed typological groupings.

\begin{tabular}{|l|l|l|l|l|l|l|}
\hline Inv. no. & Shape & Paint & $\begin{array}{l}\text { Year of } \\
\text { acquisition }\end{array}$ & $\begin{array}{l}\text { Modality of } \\
\text { acquisition }\end{array}$ & $\begin{array}{l}\text { Measurements cm } \\
\text { (H x W x D) }\end{array}$ & $\begin{array}{l}\text { State of } \\
\text { preservation }\end{array}$ \\
\hline P. 6447 & quadrangular (?) & many & unknown & unspecified & $5 \times 14 \times 27$ & fragmentary \\
\hline
\end{tabular}

Table 11: P. 6447, unclassified.

publication; their analysis could support or alter the findings of this typological study.

\section{P. 6447}

This is a fragment, unpublished, of an offering tray or possibly a soul house (Fig. 11, Table 11). Even though it is just a fragment, it shows very complex features: the top of the external and internal rims is very flat, having been cut with a sharp tool when the clay was still unbaked. The rims and the external surface of the piece were white-washed, while the internal surface of the tray was painted with an orange-reddish coat. One of the sides of the tray shows a regular rectangular depression, above which two holes for the placing of wooden sticks were pierced. The internal rim bends 90 degrees, assuming an $\mathrm{L}$ shape. No parallel has yet been found, but the internal divisions are typical of the Asyut material.

\section{Offering trays from Gebelein}

The Museo Egizio holds a collection of fourteen offering trays with Gebelein as their recorded provenance. Two trays from the museum collection were added by the author, bringing the total to sixteen trays. Nine of these trays are preserved entirely, while two are fragmentary. The other seven are fragments of trays. Tooley includes in her list at least three offering trays from Gebelein in the Egyptian Museum in Cairo, JE 54561, JE 66853, and Cairo 3/9/27/1, ${ }^{62}$ which are still awaiting proper publication. From the same site, Turin also has five soul houses and an unfired clay model of a granary, but these will be 


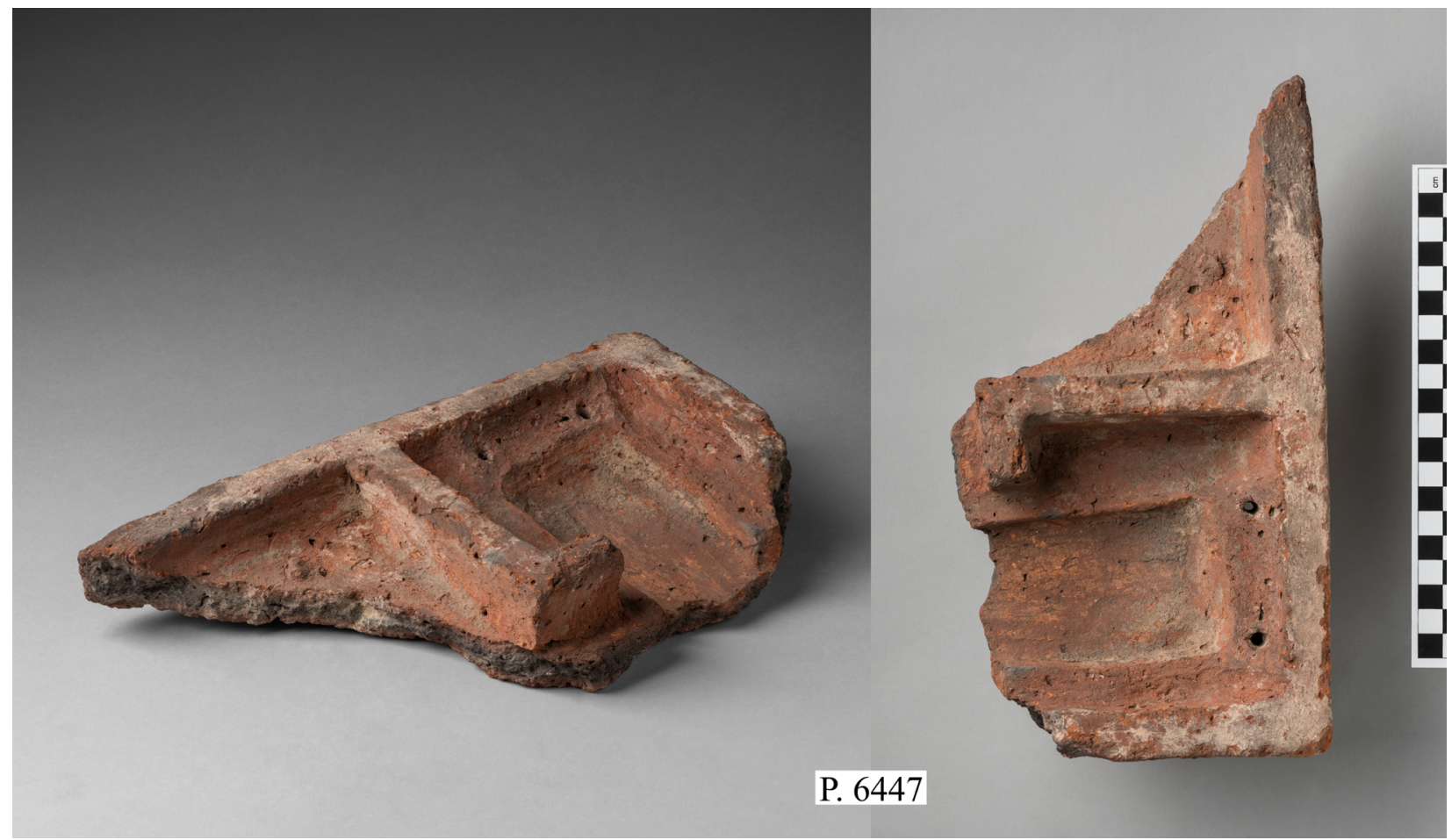

Fig. 11: P. 6447. Photos by Nicola dell'Aquila and Federico Taverni/Museo Egizio.

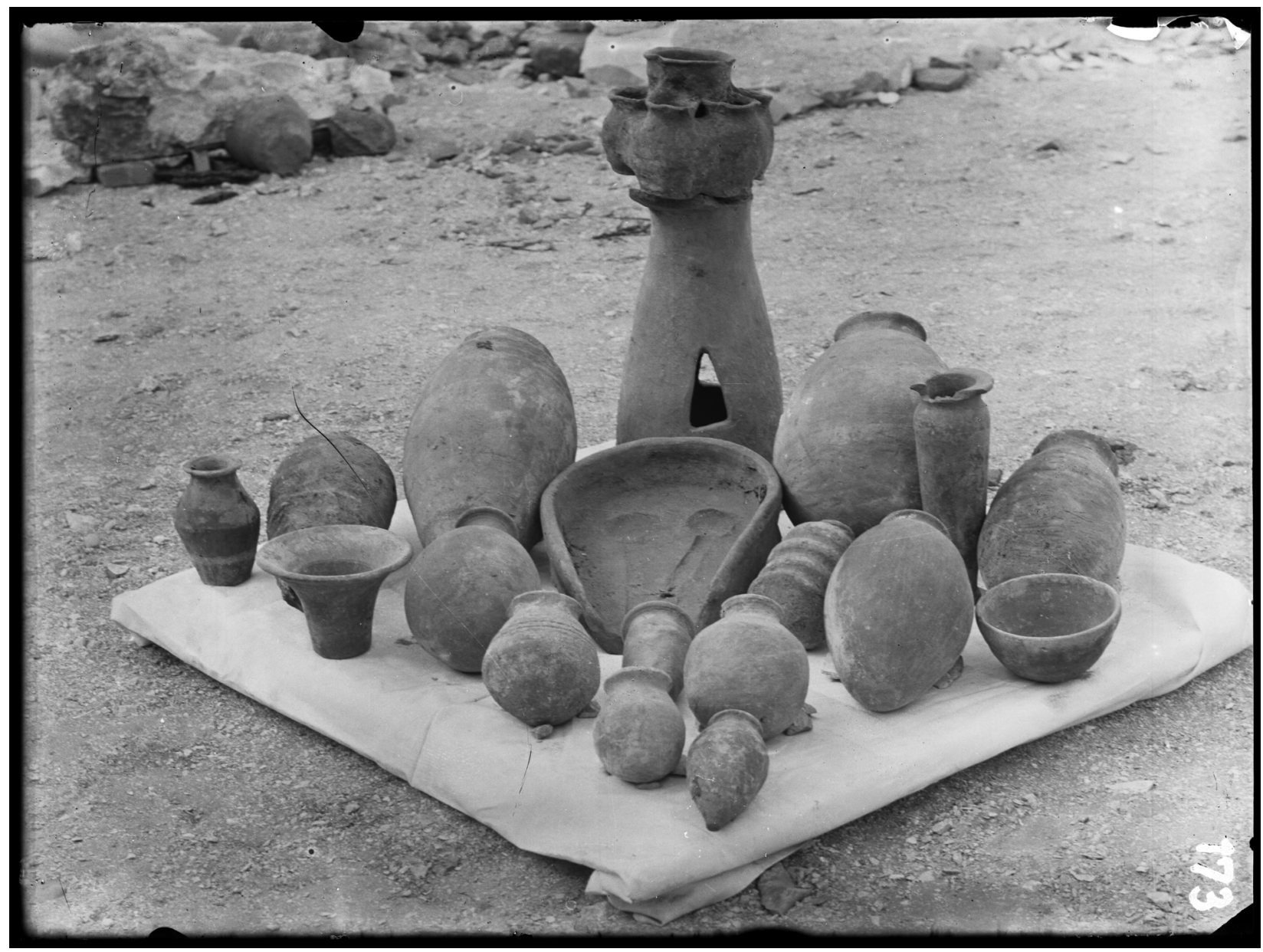

Fig. 12: S. 14259, photographed on site amongst other ceramic objects discovered during the 1912 campaign. Archivio Museo Egizio, B0173. 
discussed in another study.

The majority of the trays were recovered during excavations carried out by the Museo Egizio in Gebelein during the 1910-1914 campaigns. ${ }^{63}$ In particular, Schiaparelli's handwritten notes indicate that trays S. 11963, S. 11964, S. 11965, S. 11966 (?), ${ }^{64}$ and S. 11967 were recovered during the 1910-1911 campaign in the southern area of the necropolis of Gebelein. Trays S. 14221 (Fig. 18) and S. 14259 (Fig. 12, Fig. 15) were instead found in tombs in the northern area of the necropolis during the same campaign. Further information about the archaeological context of these trays is unavailable at the moment, but ongoing archival research in the Museo could shed new light on the context of discovery.

Two further offering trays, P. 5157 and P. 5536, were found in Gebelein, but somehow the information about their history and context was lost and they were assigned a provisional number upon arrival at the Museo Egizio. They undoubtedly come from Gebelein because they have direct parallels in the collection of objects from the same site.
In the corpus of trays from Gebelein, five different shapes can be distinguished (Fig. 13), with a predominance of the oval shape (37.5\%), followed by U-shaped trays (25\%), quadrangular ones (18.75\%), round ones $(12.5 \%)$, and one exceptional triangular specimen. The trays were either overpainted with a red wash $(62.5 \%)$ or bear no traces of paint. In the corpus, three different distinguishing characteristics were recognised, allowing to establish a typological division in three types and two variants. In two cases, the type corresponds to a specific shape: all the round trays have crossing channels (Type I); all the oval trays display T-shaped channels on their internal surface (Type III). The remaining trays, despite their heterogeneity of shapes, display circular depressions on the internal surface (Type II + Variants of Type II).

\section{Gebelein Type l: round trays with crossing channels}

These are almost perfectly round offering trays (Table 12). ${ }^{66}$ Their surface is decorated with two channels, crossing at the centre of the tray to form an $\mathrm{X}$-shape, thus dividing the upper surface into four

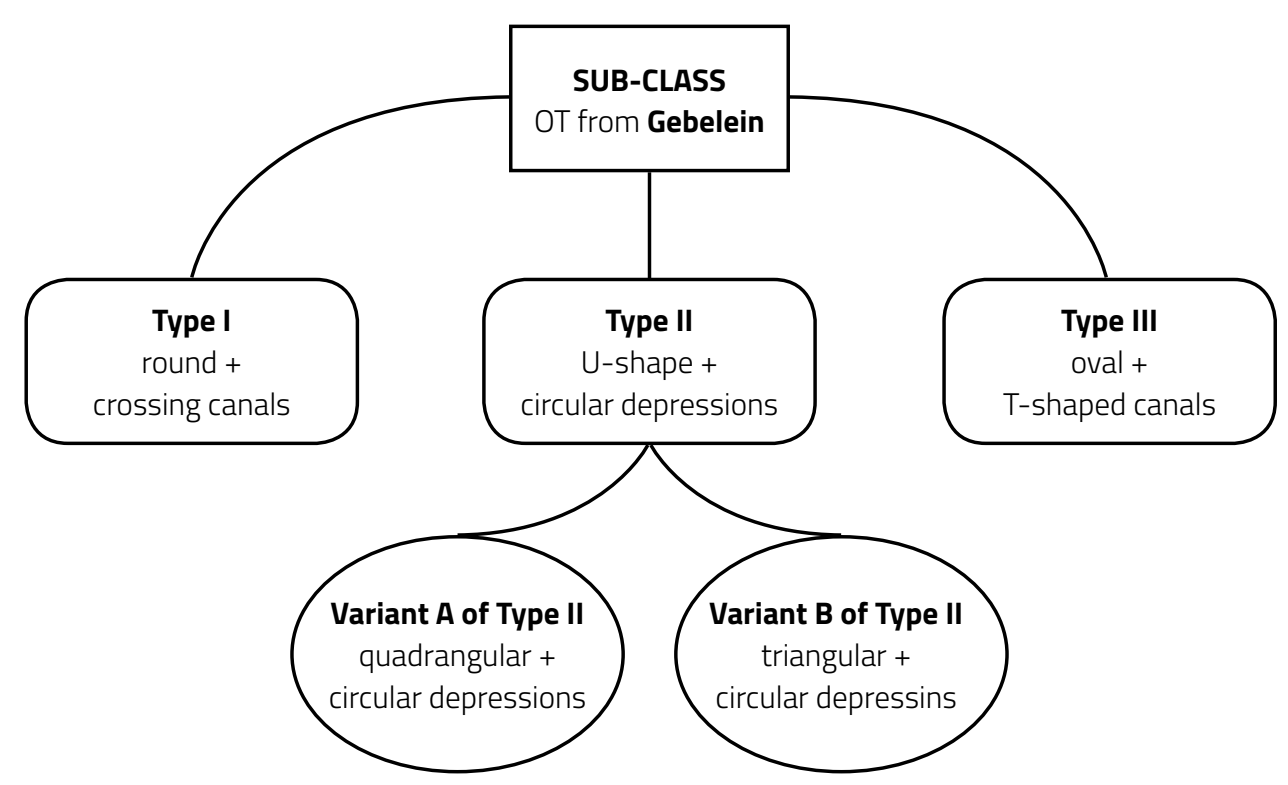

Fig. 13: Diagram summarising the types and variants discerned among the Gebelein offering trays.

\begin{tabular}{|l|l|l|l|l|l|l|}
\hline Inv. no. & Shape & Paint & $\begin{array}{l}\text { Distinctive } \\
\text { feature }\end{array}$ & $\begin{array}{l}\text { Multiple } \\
\text { offerings }\end{array}$ & $\begin{array}{l}\text { Measurements cm } \\
\text { (H x W x D) }\end{array}$ & $\begin{array}{l}\text { State of } \\
\text { preservation }\end{array}$ \\
\hline S. 16032 & round & red & crossing channels & many & $5.7 \times 22.3$ & whole \\
\hline S. 16035 & round & red & crossing channels & many & $6 \times 21 \times 24$ & almost whole \\
\hline
\end{tabular}

Table 12: Gebelein Type I. 


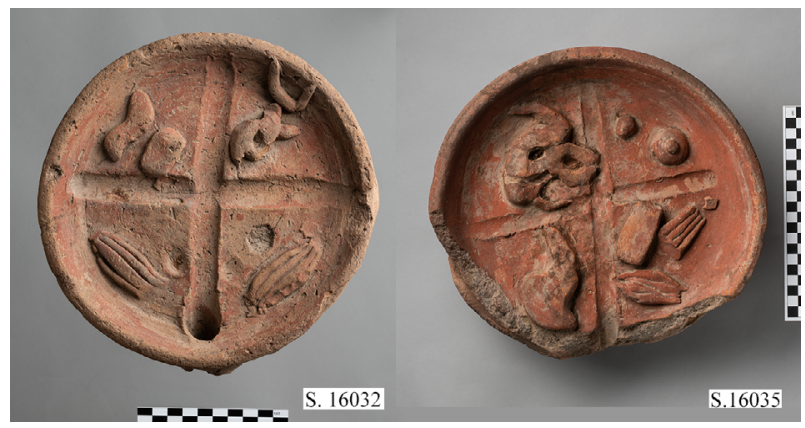

Fig. 14: S. 16032 and S. 16035. Photos by Nicola dell'Aquila and Federico Taverni/Museo Egizio.

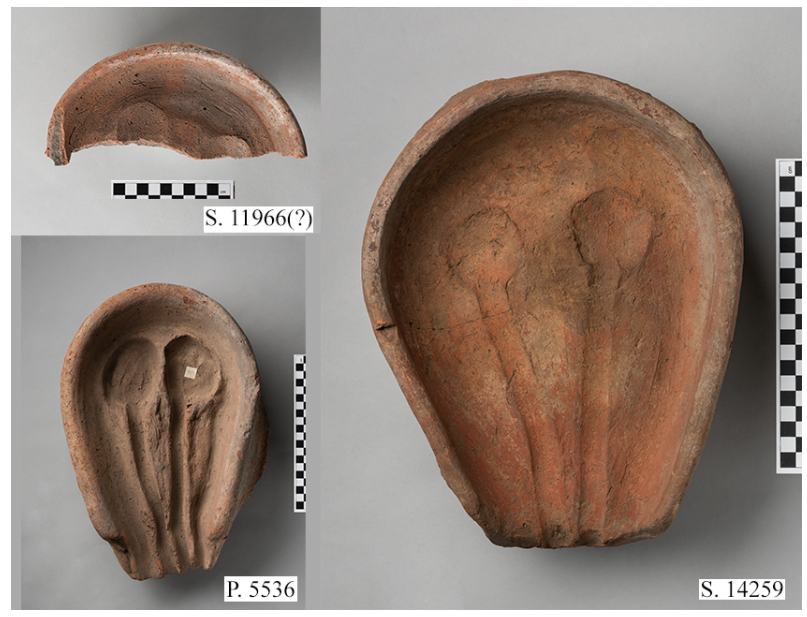

Fig. 15: S. 11996 (?), S. 14259, and P. 5536. Photos by Nicola dell'Aquila and Federico Taverni/Museo Egizio.

\begin{tabular}{|l|l|l|l|l|l|l|}
\hline Inv. no. & Shape & Paint & $\begin{array}{l}\text { Distinctive } \\
\text { feature }\end{array}$ & $\begin{array}{l}\text { Multiple } \\
\text { offerings }\end{array}$ & $\begin{array}{l}\text { Measurements cm } \\
\text { (H x W x D) }\end{array}$ & $\begin{array}{l}\text { State of } \\
\text { preservation }\end{array}$ \\
\hline S. 11966 (?) & U-shape & red & $\begin{array}{l}\text { circular } \\
\text { depressions }\end{array}$ & $?$ & $4.6 \times 20 \times 13$ & fragmentary \\
\hline S. 14259 & U-shape & red & $\begin{array}{l}\text { circular } \\
\text { depressions }\end{array}$ & no & $6 \times 23.5 \times 31$ & whole \\
\hline P. 5536 & U-shape & red & $\begin{array}{l}\text { circular } \\
\text { depressions }\end{array}$ & no & $8.5 \times 26 \times 38.5$ & whole \\
\hline
\end{tabular}

Table 13: Gebelein Type II.

quadrants. Separately modelled single offerings lie in each quadrant.

The two specimens from the Museo Egizio were coated with a bright red slip, generously applied to the internal surface of the trays (Fig. 14). Of the two, S. 16035 is the biggest offering tray in the corpus, as well as the only wheel-made tray to the knowledge of the author, who observed clear wheel-lines on the internal and external surfaces.

Even though round trays also appear in Armant ${ }^{67}$ and Esna, ${ }^{68}$ none of them shows crossing channels. The only direct parallels to the Gebelein round type are an unprovenanced offering tray in the British Museum (EA $43446^{69}$ ), and E131 in the Museu Nacional de Arqueologia in Lisbon. ${ }^{70}$ Until proven otherwise, the combination of the round shape and cross-shaped decoration is attested only in Gebelein.

\section{Gebelein Type II: circular depressions}

The second type from Gebelein is characterised by the presence of two or more circular depressions on the surface of the tray, from which channels depart, connecting the depressions to the low frontal rim (Table 13).

- S. 11966 (?) (Fig. 15) consists of the remaining part of a U-shaped offering tray. The circular depressions in the back of the tray are almost completely preserved. Unpublished.

- S. 14259 (Fig. 15, Fig. 12) is a U-shaped tray, with an open front, coated with a red slip. The depressions are regular and were probably created by a spherical tool. Unpublished.

- P. 5536 (Fig. 15) is quite similar to the previous one, but larger. Even though the object bears a Provvisorio number, its provenance from Gebelein is practically certain. Unpublished.

Direct parallels for this group of objects can be found at Qubbet el-Hawa ${ }^{71}$ and in the Theban necropolis, where Petrie recovered numerous trays during his excavations; ${ }^{72}$ among the specimens in the published drawings, number 612 on plate XXI has the same shape and circular depressions as the 
specimens in the Museo Egizio. Furthermore, the occurrence of circular depressions can also be observed in number 611 and 613 on the same plate. Dieter Arnold also excavated several offering trays. Among his finds, N 3.1 is the one that most resembles the specimens found by Petrie. ${ }^{73}$ Furthermore, Budka published a number of fragments of offering trays from the Assasif excavations, the most direct parallel to the Turin specimen being cat. 1246 no. K02/88.6. ${ }^{74}$ Since this shape appears mostly at these two sites, it seems likely it was mainly manufactured in the Gebelein-Thebes area, even though it appears in trays from the Dendera corpus.

Belonging to this type, but quadrangular in form, is Variant A of Type II, comprising three quadrangular offering trays ${ }^{75}$ with circular depressions on their internal surface (Table 14):

- S. 11963 (Fig. 16) is quite rectangular; the rim is of the same height across the perimeter of the tray, but is interrupted by two circular depressions in correspondence with the two channels. Around the channels and the two circular depressions, several offerings are visible, including a recognisable ox at the very centre of the tray.

- S.11964 (Fig. 16) is the best preserved of the two. It shows a protruding spout on the front. The internal surface bears four round depressions at the corners. The regularity of the depressions suggests that they were produced by pressure from a spherical tool on the still unbaked clay. Two short channels run at the centre of the object. An ox leg lies on the left side of the tray, across one of the channels.

- S. 11967 (Fig. 16) is a rather conspicuous fragment, showing some interesting features. Two corners of the high rim are preserved, as are some offerings: a calf, a head, and some vegetables. Two circular depressions are visible, one of them completely preserved and of the same nature as those described above, while the other is partially damaged.

The Museo Egizio holds in its collection a very small tray, S. 11965 (Fig. 17, Table 15), triangular in shape, with no direct parallels and, as far as I know, the only triangular pottery offering tray known from Egypt. It features two very regular circular depressions on the longer side of the triangle and a chan-

\begin{tabular}{|l|l|l|l|l|l|l|}
\hline Inv. no. & Shape & Paint & $\begin{array}{l}\text { Distinctive } \\
\text { feature }\end{array}$ & $\begin{array}{l}\text { Multiple } \\
\text { offerings }\end{array}$ & $\begin{array}{l}\text { Measurements cm } \\
\text { (H x W x D) }\end{array}$ & $\begin{array}{l}\text { State of } \\
\text { preservation }\end{array}$ \\
\hline S. 11963 & rectangular & red & $\begin{array}{l}\text { circular } \\
\text { depressions }\end{array}$ & many & $5.5 \times 21.5 \times 28$ & whole \\
\hline S. 11964 & rectangular & red & $\begin{array}{l}\text { circular } \\
\text { depressions }\end{array}$ & one & $5.5 \times 22.5 \times 28.5$ & whole \\
\hline S. 11967 & rectangular & no & $\begin{array}{l}\text { circular } \\
\text { depressions }\end{array}$ & many & $4.8 \times 25 \times 31$ & fragmentary \\
\hline
\end{tabular}

Table 14: Gebelein Type II Variant A.

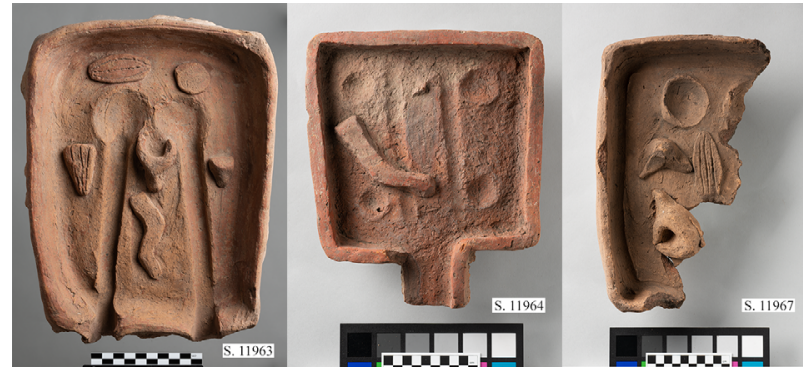

Fig. 16: S. 11963, S. 11964, and S. 11967. Photos by Nicola dell'Aquila and Federico Taverni/Museo Egizio.

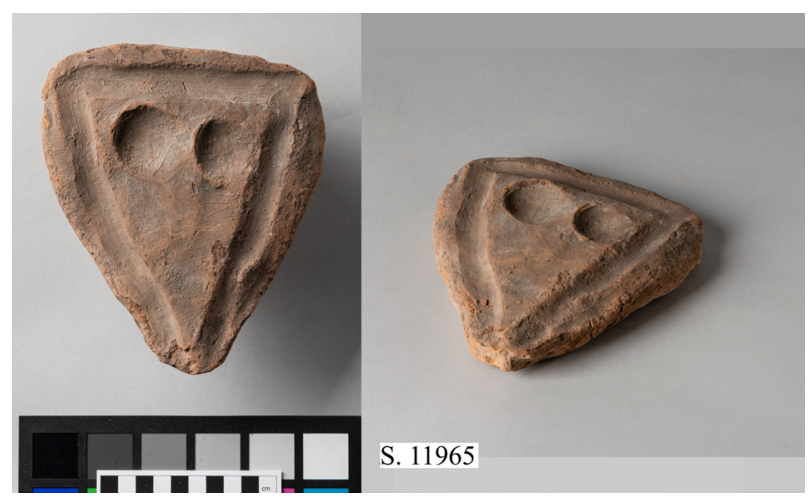

Fig. 17: S. 11965. Photos by Nicola dell'Aquila and Federico Taverni/Museo Egizio. 


\begin{tabular}{|l|l|l|l|l|l|l|}
\hline Inv. no. & Shape & Paint & $\begin{array}{l}\text { Distinctive } \\
\text { feature }\end{array}$ & $\begin{array}{l}\text { Multiple } \\
\text { offerings }\end{array}$ & $\begin{array}{l}\text { Measurements cm } \\
\text { (H x W x D) }\end{array}$ & $\begin{array}{l}\text { State of } \\
\text { preservation }\end{array}$ \\
\hline S. 11965 & triangular & no & $\begin{array}{l}\text { circular } \\
\text { depressions }\end{array}$ & none & $2.6 \times 15.5 \times 18$ & whole \\
\hline
\end{tabular}

Table 15: Gebelein Type II Variant B.

\begin{tabular}{|l|l|l|l|l|l|l|}
\hline Inv. no. & Shape & Paint & $\begin{array}{l}\text { Distinctive } \\
\text { feature }\end{array}$ & $\begin{array}{l}\text { Multiple } \\
\text { offerings }\end{array}$ & $\begin{array}{l}\text { Measurements cm } \\
\text { (H x W x D) }\end{array}$ & $\begin{array}{l}\text { State of } \\
\text { preservation }\end{array}$ \\
\hline S. 14221 & U-shape & no & $?$ & $?$ & $3.9 \times 9 \times 29$ & fragmentary \\
\hline
\end{tabular}

Table 16: Gebelein, unclassified fragment.

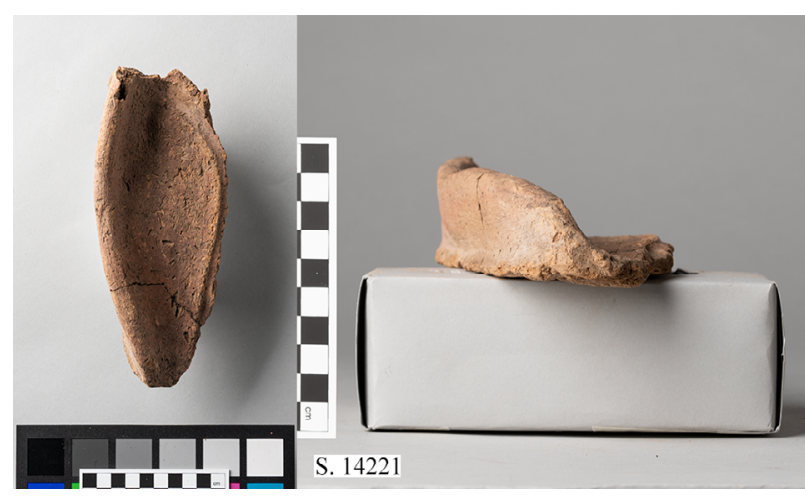

Fig. 18: S. 14221. Photos by Nicola dell'Aquila and Federico Taverni/Museo Egizio.

nel that runs along the object's perimeter.

This unpublished tray does not have any parallel in the known corpus. I have categorised it as Variant

\section{B of Type II.}

Finally, there is a fragment of a U-shaped offering, unpublished, whose only preserved superficial feature is the side of a channel (Fig. 18, Table 16). The object is too badly preserved to fall within any of the proposed categories.

\section{Gebelein Type III, or "Gebelein-Armant" type}

Gebelein has yielded a great quantity of oval-shaped offering trays, with a continuous rim that encircles the upper surface of the piece. At the issue of the channelling, the rim has an opening a few millimetres in diameter to allow liquids to flow out of the tray. The channels divide the surface into two areas, one for the offerings, which always include

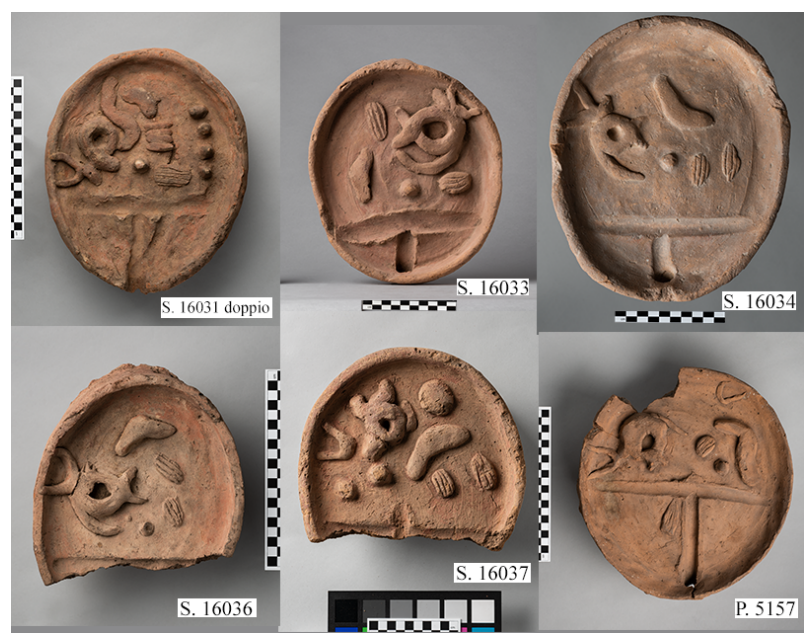

Fig. 19: S. 16031 doppio, S. 16033, S. 16034, S. 16036, S. 16037, and P. 5157. Photos by Nicola dell'Aquila and Federico Taverni/Museo Egizio.

the tied-down ox, and a second area characterised by T-shaped channels, modelled by finger impression on the still unfired clay. Seven offering trays in the Museo Egizio ${ }^{76}$ belong to this type (Fig. 19, Table 17).

The same kind of offering tray was found in Armant, ${ }^{77}$ where twenty-six trays were recovered by Mond and Myers in tombs 1213 and $1214 .^{78}$ Some of them are now in the Liverpool Museum. ${ }^{79}$ As suggested by the choice of name for the present type, I believe that the similarity of the Gebelein trays to the Armant specimens, as well as the proximity of the two sites, suggest that this style was specific to the Gebelein-Armant area. This hypothesis helps to suggest a provenance for other trays, both in the Museo Egizio and in other European collections. Other specimens meeting the same description include: EA 21702 in the British Museum $;^{80}$ UC18420, UC18421, UC38996 in the Petrie 


\begin{tabular}{|l|l|l|l|l|l|l|}
\hline Inv. no. & Shape & Paint & $\begin{array}{l}\text { Distinctive } \\
\text { feature }\end{array}$ & $\begin{array}{l}\text { Multiple } \\
\text { offerings }\end{array}$ & $\begin{array}{l}\text { Measurements cm } \\
\text { (H x W x D) }\end{array}$ & $\begin{array}{l}\text { State of } \\
\text { preservation }\end{array}$ \\
\hline $\begin{array}{l}\text { S. } 16031 \text { numero } \\
\text { doppio }\end{array}$ & oval & no & $\begin{array}{l}\text { T-shaped } \\
\text { channels }\end{array}$ & many & $6.3 \times 25.5 \times 30.5$ & whole \\
\hline S. 16033 & oval & red & $\begin{array}{l}\text { T-shaped } \\
\text { channels }\end{array}$ & many & $5 \times 21 \times 24$ & whole \\
\hline S. 16034 & oval & red & $\begin{array}{l}\text { T-shaped } \\
\text { channels }\end{array}$ & many & $4.6 \times 22 \times 26$ & whole \\
\hline S. 16036 & oval & red & $\begin{array}{l}\text { T-shaped } \\
\text { channels }\end{array}$ & many & $5 \times 21 \times 22$ & fragmentary \\
\hline S. 16037 & oval & red & $\begin{array}{l}\text { T-shaped } \\
\text { channels }\end{array}$ & many & $4.5 \times 20.5 \times 24$ & fragmentary \\
\hline P. 5157 & oval & no & $\begin{array}{l}\text { T-shaped } \\
\text { channels }\end{array}$ & many & $4.8 \times 28 \times 31$ & almost whole \\
\hline
\end{tabular}

Table 17: Gebelein Type III.

\begin{tabular}{|l|l|l|l|l|l|l|l|l|}
\hline Inv. no. & Shape & Paint & $\begin{array}{l}\text { Distinctive } \\
\text { feature }\end{array}$ & $\begin{array}{l}\text { Multiple } \\
\text { offerings }\end{array}$ & $\begin{array}{l}\text { Year of } \\
\text { acquisition }\end{array}$ & $\begin{array}{l}\text { Modality of } \\
\text { acquisition }\end{array}$ & $\begin{array}{l}\text { Measurements cm } \\
\text { (H x W x D) }\end{array}$ & $\begin{array}{l}\text { State of } \\
\text { preservation }\end{array}$ \\
\hline S. 1189 & round & red & T-shaped channels & many & $1900-1901$ & purchased & $3 \times 28.5$ & fragmentary \\
\hline S. 1190 & round & no & T-shaped channels & many & $1900-1901$ & purchased & $4 \times 21.5$ & almost whole \\
\hline
\end{tabular}

Table 18: Gebelein Type III (provenance unknown, attributed to type).

Museum; 1973.1.349 in Liverpool; ${ }^{81}$ F. 1939/2.39 in the Rijksmuseum van Oudheden in Leiden; ${ }^{82}$ and $\mathrm{M} 6212^{83}$ and $\mathrm{M} 7855^{84}$ in the Manchester Museum. A tray in Amsterdam, APM 8540, is said to come from Saqqara, ${ }^{85}$ as well as another specimen. ${ }^{86}$ However, this provenance can be regarded as doubtful, as if true it would mean that these are the only two trays ever found in Saqqara, ${ }^{87}$ whereas the northernmost limit of distribution of trays is known to be Lahun. 88

\section{S. 1189 and S. 1190}

These two objects ${ }^{89}$ were purchased by Schiaparelli in Egypt in 1900-1901, place of purchase not specified (Fig. 20, Table 18). At first sight, observation of the clay and of the way they were modelled and fired suggests that they do not belong to the same site. Nonetheless, they could have the same provenance, given the evidence of other very different trays recovered in the same context or necropolis. Judging from the shape of the base, it seems that both trays are southern products. The high concentration of round, oval, and U-shaped trays in southern Egypt points to this region as the place of pro-

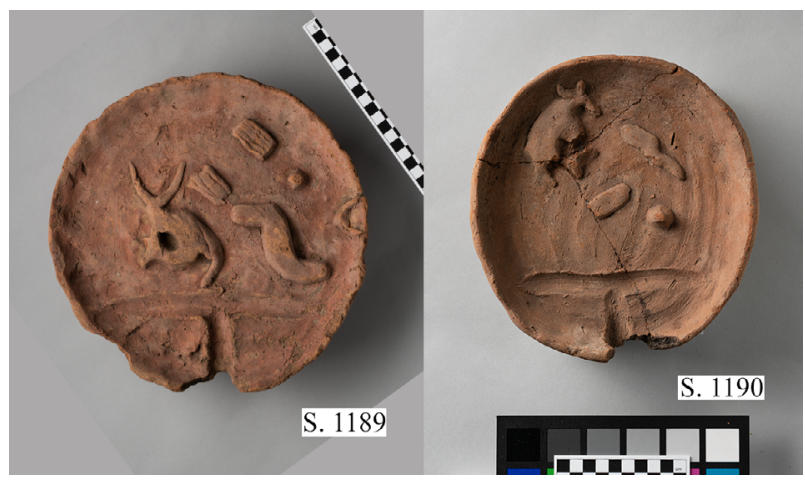

Fig. 20: S. 1189 and S. 1190. Photos by Nicola dell'Aquila and Federico Taverni/Museo Egizio.

duction. Looking at the trays in the collection of the Liverpool museum, mainly coming from Armant, and at those in the Museo Egizio that come from Gebelein, it could be said that S. 1189 and S. 1190 fall in the Gebelein Type III described in the previous section. In the arrangement of offerings, the T-shaped channels in the front of the trays, and the treatment of the surface they are similar to trays from Gebelein and Armant, which seem to be their most plausible places of production. 


\begin{tabular}{|l|l|l|l|l|l|l|l|l|}
\hline Inv. no. & Shape & Paint & $\begin{array}{l}\text { Distinctive } \\
\text { feature }\end{array}$ & $\begin{array}{l}\text { Spatial } \\
\text { Arrangement }\end{array}$ & $\begin{array}{l}\text { Year of } \\
\text { acquisition }\end{array}$ & $\begin{array}{l}\text { Modality of } \\
\text { acquisition }\end{array}$ & $\begin{array}{l}\text { Measurements cm } \\
\text { (H x W x D) }\end{array}$ & $\begin{array}{l}\text { State of } \\
\text { preservation }\end{array}$ \\
\hline P. 6456 & round & red & bound ox & dividing wall & post 1824 & unspecified & $5.5 \times 40.5$ & fragmentary \\
\hline
\end{tabular}

Table 19: P. 6456, unclassified specimen, provenance unknown, possibly from Armant-Gebelein area.

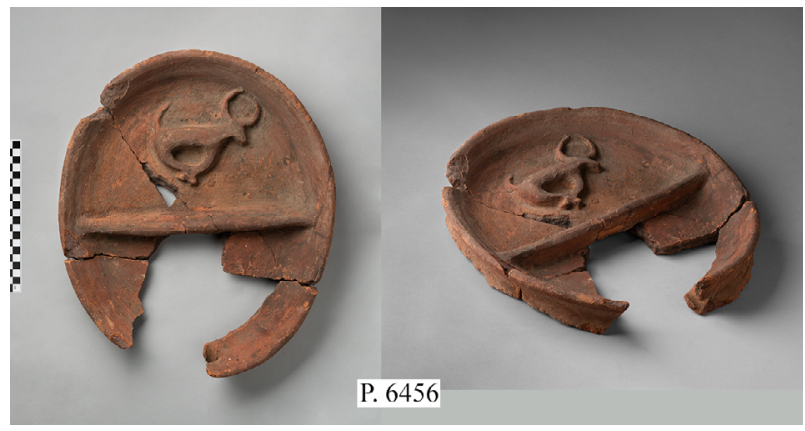

Fig. 21: P. 6456. Photos by Nicola dell'Aquila and Federico Taverni/Museo Egizio.

\section{P. 6456}

The museum sources provide no information about the origin of this rather large tray, which is unpublished (Fig. 21, Table 19). It was recomposed from several fragments. It is of well-baked Nile silt and was coated with a brown-reddish slip. Although not perfectly preserved, it seems quite certain that the only represented offering was a tied-down bull, still entirely visible in the middle, at the back of the tray. This tray, too, was divided into two areas, one for the offerings and another possibly for the channels. The division was made by means of an internal wall. From the preserved fragment it is not clear if the piece was actually completely closed and pierced on the front to allow liquids to flow out, or if it was open. It is ascribable to the oval-tray type or possibly to that of U-shaped trays. The only parallel is an offering tray recovered in Armant by Mond and Myers. Excavated in tomb 1213, the tray from Armant also shows a single bull resting on the back surface of the plate. The dividing wall seems modelled similarly to the one in P. 6456. The latter could thus come from Armant, but this is not certain. It is also plausible

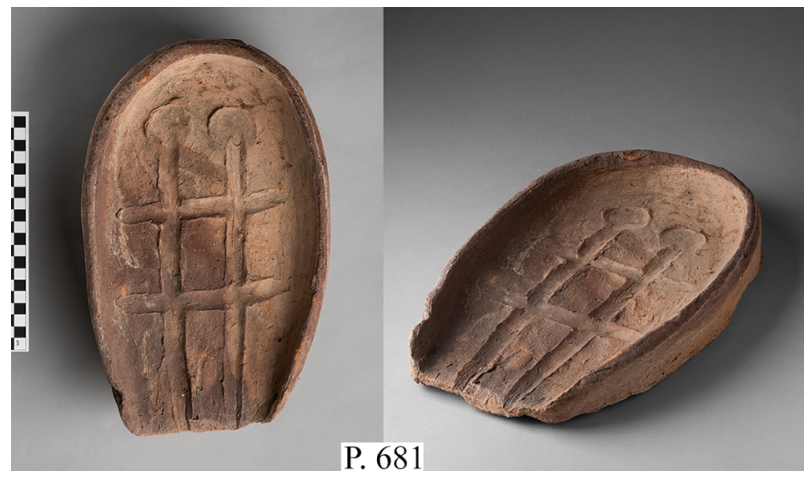

Fig. 22: P. 681. Photos by Nicola dell'Aquila and Federico Taverni/Museo Egizio.

that this tray comes from Gebelein, but the different look and treatment of the material compared to the other trays in the Turin collection appear to suggest otherwise. In sum, given the high concentration of such trays and the similarities of objects of this category in Armant and Gebelein, a possible provenance is Upper Egypt, Armant-Gebelein area.

\section{Unprovenanced offering trays P. 681}

P. 681 is unprovenanced and its year of accession to the collection unknown (Fig. 22, Table 20). Made of Nile clay, this U-shaped tray (unpublished) was coated with a brown slip which is visible on the internal and external surfaces of the piece. Two channels depart from two circular depressions on the back rim. Two perpendicular channels cross the longitudinal ones in the centre of the tray, resulting in a grid pattern.

Similarly-shaped offering trays have been mainly found in Upper Egypt. U-shaped trays are frequently attested in Dendera, Esna, and Western Thebes, with some specimens also occurring in Armant and Gebelein. The circular depressions in the centre or in

\begin{tabular}{|l|l|l|l|l|l|l|}
\hline Inv. no. & Shape & Paint & $\begin{array}{l}\text { Distinctive } \\
\text { feature }\end{array}$ & $\begin{array}{l}\text { Year of } \\
\text { acquisition }\end{array}$ & $\begin{array}{l}\text { Measurements cm } \\
\text { (H x W x D) }\end{array}$ & $\begin{array}{l}\text { State of } \\
\text { preservation }\end{array}$ \\
\hline P. 681 & U-shape & white & crossing channels + circular depressions & unknown & $5.2 \times 21 \times 32.5$ & whole \\
\hline
\end{tabular}

Table 20: P. 681, unclassified specimen, provenance unknown, possibly from Thebes. 


\begin{tabular}{|l|l|l|l|l|l|l|}
\hline Inv. no. & Shape & Paint & $\begin{array}{l}\text { Distinctive } \\
\text { feature }\end{array}$ & $\begin{array}{l}\text { Year of } \\
\text { acquisition }\end{array}$ & $\begin{array}{l}\text { Measurements cm } \\
\text { (H x W x D) }\end{array}$ & $\begin{array}{l}\text { State of } \\
\text { preservation }\end{array}$ \\
\hline P. 730/1 & U-shape & $\begin{array}{l}\text { red }+ \\
\text { white }\end{array}$ & $\begin{array}{l}\text { U-shaped } \\
\text { channels }\end{array}$ & $?$ & $6 \times 20.5 \times 30$ & whole \\
\hline P. 730/2 & U-shape & red & $\begin{array}{l}\text { U-shaped } \\
\text { channels }\end{array}$ & $?$ & $5.4 \times 18 \times 27$ & whole \\
\hline P. 730/3 & U-shape & brown & $\begin{array}{l}\text { U-shaped } \\
\text { channels }\end{array}$ & $?$ & $6.5 \times 24.5 \times 31$ & fragmentary \\
\hline P. 730/4 & U-shape & brown & $\begin{array}{l}\text { U-shaped } \\
\text { channels }\end{array}$ & $?$ & $4.5 \times 27 \times 21$ & $\begin{array}{l}\text { two } \\
\text { fragments }\end{array}$ \\
\hline
\end{tabular}

Table 21: P. 730/1-4, unclassified specimens, presumably from Upper Egypt.

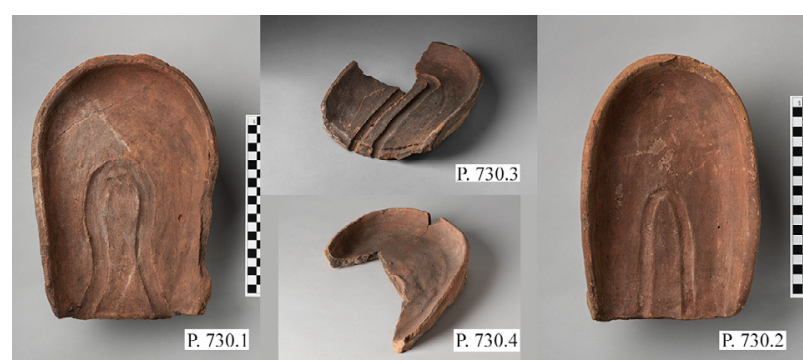

Fig. 23: P. 730/1, P. 730/2, P. 730/3, P. 730/4. Photos by Nicola dell'Aquila and Federico Taverni/Museo Egizio.

the back are found in Dendera, ${ }^{90}$ Western Thebes, ${ }^{91}$ Gebelein $^{92}$ and Esna. ${ }^{93}$

In specimens from Dendera, Gebelein and Western Thebes, the circular depressions are almost always two in number. ${ }^{94}$ The double depression appears to be typical of these three sites only, since it is not attested elsewhere. The crossing channels are found exclusively on trays excavated in the Theban Necropolis. ${ }^{95}$ The combination of U-shape form, circular depressions, and grid channels points to Upper Egypt as the region of origin of the tray and Western Thebes as the possible site of provenance.

\section{P. 730/1, P. 730/2, P. 730/3, P. 730/4}

These four offering trays (Fig. 23, Table 21), all unpublished, have been grouped under the same provisional inventory number for good reason: from a

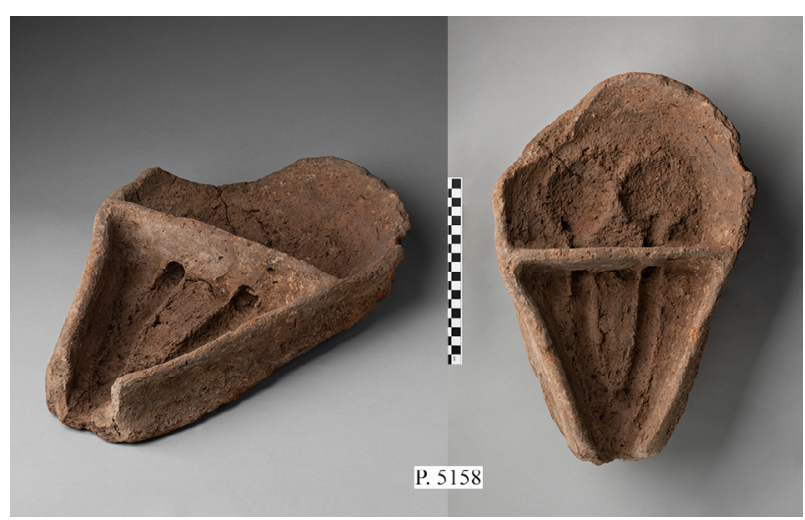

Fig. 24: P. 5158. Photos by Nicola dell'Aquila and Federico Taverni/Museo Egizio.

material and formal point of view, they appear to be linked and share the same manufacturing techniques (they are all handmade) and a similar treatment of the internal and external surfaces (reddish-brown wash copiously applied on the surface, finger-traced U-shaped channels). Unfortunately, they do not share the same degree of preservation: while P. $730 / 1$ and P. $730 / 2$ are completely preserved, P. $730 / 3$ is fragmentary and P. 730/4 is just a fragment, whose features are barely visible. All four objects are U-shaped trays with an internal channel, itself U-shaped, with its extremities towards the low frontal rim of the tray. Once again, this kind of decoration and the shape of the trays themselves point to an Upper Egyptian production. Direct parallels, especially the U-shaped channels, can be found among the trays recovered in the Theban necropolis ${ }^{96}$ and at Qubbet el-Hawa. ${ }^{97}$

\begin{tabular}{|l|l|l|l|l|l|l|l|}
\hline Inv. no. & Shape & Paint & $\begin{array}{l}\text { Distinctive } \\
\text { feature }\end{array}$ & $\begin{array}{l}\text { Spatial } \\
\text { Arrangement }\end{array}$ & $\begin{array}{l}\text { Year of } \\
\text { acquisition }\end{array}$ & $\begin{array}{l}\text { Measurements cm } \\
\text { (H x W x D) }\end{array}$ & $\begin{array}{l}\text { State of } \\
\text { preservation }\end{array}$ \\
\hline P. 5158 & U-shape & no & circular depressions & dividing wall & $1910-1920$ & $6.5 \times 28.5 \times 41.5$ & whole \\
\hline
\end{tabular}

Table 22: P. 5158, unclassified specimen, with parallels at Dendera and Thebes. 


\section{P. 5158}

This tray (unpublished) became part of the collection of the Museo sometime between 1910 and 1920 (Fig. 24, Table 22). It is quite a large specimen, of very rough Nile clay, unsmoothed. It could be defined as a U-shaped tray, with a very large back featuring an extroverted rim. The back is separated from the front of the tray by a dividing wall, perpendicular to the direction of the channels, pierced in two points in correspondence with the two channels. The surface of the back shows two circular depressions, from which the channels depart. It seems quite clear that if libations were actually poured on the object, they would have been poured on the back of the tray; otherwise the pierced dividing wall would have been useless. P. 5158 is not very well preserved, its state probably being due to poor baking. Direct parallels for this object can be found in Dendera and Thebes. ${ }^{98}$ While there is no conclusive evidence, tray P. 5158 likely comes from the Dendera-Thebes area.

\section{Conclusions}

This survey of the trays kept in the Museo Egizio and of their parallels yields a few important insights, which may eventually help to establish a common methodology for the study of this category of artefacts:

- Trays from the same site tend to strongly resemble each other and site typologies can be established by grouping types according to common characteristics.

The typologies created for the trays from Asyut and Gebelein are quite explicative in this regard. I have divided the Siutian corpus into 4 types and 5 variants, in which the majority of the preserved and fragmentary trays discovered by all the missions that worked at the site can be grouped. I have done the same with the Gebelein corpus, with the sole difference that Type III includes trays from both Gebelein and Armant, highlighting evident common characteristics and pointing to a probable relationship between these two sites.

Besides giving an accurate count of known trays from the same sites, the survey has also shed light on the "popularity" of certain shapes and features, highlighting local trends and common representational aims. For example, Variant A of Type II in the
Siutian corpus presents three basic characteristics: the quadrangular shape, the central ox head at the back of the tray, and the L-shaped walls on the front. All these characteristics appear at other sites but never combined, pointing to a peculiar regionalism of the site of Asyut. Not only do trays from the same site look alike and could be grouped in typologies according to shape, arrangement of the offerings, and other macro-characteristics, but it is possible to see that some features occur at other site outside of local boundaries, sometimes with such frequency that it is possible to argue for the existence of an actual style. The most eloquent example is the occurrence of trays with the same shape and arrangement of offerings behind $\mathrm{T}$-shaped channels at Gebelein and Armant.

Not surprisingly, provenanced trays find their closest parallels not only among specimens from the same site, but also among trays found in geographically neighbouring sites, as in the cases of Armant-Gebelein, Gebelein-Thebes, and Thebes-Dendera.

In some cases, the resemblance between unprovenanced trays now kept in various museum collections and trays of known archaeological context and provenance is sometimes so striking that it suggests that the unprovenanced trays actually came from the site where the most parallel specimens are attested. Through the survey, the already theorised and recognised northern predominance of square trays versus the occurrence of oval or round shapes in the South is confirmed, and further supported by a collection of specimens which have never been properly published or mentioned in the literature. Thanks to these evident similarities, it could be possible to assign a likely provenance to the unprovenanced pieces in the Turin museum's collection, but only if the provenanced parallels are cross-correlated and if the number of parallels is high enough to make attributions plausible. Through this method, it is also possible to limit the range of likely provenances of some trays which had never been associated with their parallels beforehand. It is evident that this method could only stand to benefit from a broader coverage of all the known trays in collections and excavations, especially those which have no provenance. In this way, and through the mapping of provenanced specimens, some quantitative, 
qualitative and statistical observations could be made, greatly contributing to the work of scholars of the subject by shedding new light on a category of objects that was quite popular and counts hundreds of specimens that are awaiting proper study and publication.

\section{Notes}

${ }^{1}$ I want to express my gratitude for the useful advice received from all the curators of the Museo Egizio, especially Paolo Del Vesco, Federico Poole, and Enrico Ferraris, who granted me the opportunity to study the objects of the collection on several occasions. Furthermore, my gratitude goes to Vera and Derek Allen and Jean-Yves Bart (MISHA, University of Strasbourg) for their language revisions. Lastly, I wish to thank the anonymous reviewers for allowing me to drastically improve this paper thanks to their useful comments.

${ }^{2}$ Ridley, Life and Times of Bernardino Drovetti, 1998. Moiso, in Museo Egizio, 2015, pp. 23-24.

${ }^{3}$ For an overview of the various campaigns, see: Moiso, Storia del Museo Egizio, 2016, p. 64. Del Vesco and Moiso (eds.), Missione Egitto, 2017.

${ }^{4}$ It should be noted that C. numbers also include objects acquired before and after the purchase of the Drovetti collection, and S. numbers objects acquired by the museum even after the end of Schiaparelli's directorship in 1928, until recent times.

${ }^{5}$ Extremely useful were the lists provided in the publications by Tooley, “Burial Customs”, 1989, pp. 254-93; Leclère, in Muller (ed.), «Maquettes Architecturales», 2001, pp. 103-04; and Kilian, in Kahl et al. (eds.), Seven Seasons at Asyut, 2012, pp. 115-16.

${ }^{6}$ See below, section 2, Current state of research.

${ }^{7}$ Niwinski, EtudTrav 8 (1975), pp. 103-04; Tooley, “Burial Customs”, pp. 249, 296.

${ }^{8}$ Instead of giving the exact number of offerings present on the surface, they have been divided into the following categories: none $(=0)$, one $(=1)$, few $(>1)$, many (>3).

${ }^{9}$ I am extremely grateful to Paolo Marini for our methodological discussions. The guidelines followed in the typological division were largely inspired by his doctoral thesis "Contenitori di ushabti”, 2016.

${ }^{10}$ Nordström and Bourriau, in Arnold (ed.), Introduction to Ancient Egyptian Pottery, 1993, pp. 169-82; Bourriau, in Hawass and Richards (eds.), Archaeology and Art of Ancient Egypt, 2007, pp. 137-44.

${ }^{11}$ For the most recent discoveries of offering trays in archaeological contexts, see: Budka, Bestattungsbrauchtum, 2010, pp. 742-44, pls. 57-58. Lopez Grande, in Aston et al. (eds.), Potter's Tree, 2011, pp. 583, p. 598 fig. 2.e. Consonni and Sesana, in Bader et al. (eds.), Vienna 2, 2016, pp. 103-18. Barahona Mendieta, BCE 28 (2018), pp. 171-77. Pérez Die, "The Cemetery". Further literature is provided by the authors mentioned in footnote 14 .

12 Raven, in OMRO 72 (1922), pp. 7-14.

${ }^{13}$ Leclère, in Muller (ed.), «Maquettes Architecturales», 2001, p. 101; Spence, in Aston et al. (eds.), Potter's Tree, 2011, p. 905; Kilian, in Kahl et al. (eds.), Seven Seasons

at Asyut, 2012, pp. 105-18.

${ }^{14}$ Main bibliography: Petrie, Kahun, 1890, pp. 24-25. Petrie, Rifeh, 1907, p. 15 ff. Petrie, in Hastings (ed.) Encyclopaedia of Religion and Ethics, 1908-1926, IX, pp. 755-56. Niwinski, EtudTrav 8 (1975), pp. 103-04. Slater, Archaeology of Dendereh, 1974. Kuentz, in BIFAO 81 (1981), pp. 243-82; Niwinski, in Helck and Otto (eds.), Lexikon der Ägyptologie, V, 1984, pp. 806-13. Tooley, “Burial Customs”, 1989. Leclère in Muller (ed.), "Maquettes Architecturales», 2001. Kilian, in Kahl et al. (eds.), Seven Seasons at Asyut, 2012.

${ }^{15}$ Leclère, in Muller (ed.), «Maquettes Architecturales», 2001, pp. 99-122. Spence, in Aston et al. (eds.), Potter's Tree, 2011, pp. 895-914.

${ }^{16}$ Kahl et al., SAK 41 (2012), pp. 199-201; Kilian, in Kahl et al. (eds.), Seven Seasons at Asyut, 2012, pp. 112-14; Kilian, in Kahl et al. (eds.), Asyut, Tomb III, 2016, pp. 173-96.

${ }^{17}$ Petrie, Gizeh and Rifeh, 1907, p. 15.

${ }^{18}$ Kilian, in Kahl et al. (eds.), Seven Seasons at Asyut, 2012, pp. 111-12.

${ }^{19}$ Niwinski, EtudTrav 8 (1975), p. 79.

${ }^{20}$ Tooley, “Burial Customs”, 1989, p. 251.

${ }^{21}$ Slater, Archaeology of Dendereh, 1974, pp. 302-13.

22 Tooley, "Burial Customs”, 1989, pp. 249, 296; Leclère, in Muller (ed.), «Maquettes architecturales», 2001, pp. 118-19; Spence, in Aston et al. (eds.), Potter's Tree, 2011, p. 901.

${ }^{23}$ Tooley, “Burial Customs”, 1989, p. 297.

${ }^{24}$ This statement by Spence refers to soul houses, but it can also be applied to offering trays; Spence, in Aston et al. (eds.), Potter's Tree, 2011, p. 901.

${ }^{25}$ Borghouts, in Helck and Otto (eds.), Lexikon der Ägyptologie, III, 1980, pp. 1014-015; Kuentz, BIFAO 81 (1981), p. 245; Hölzl, in Amenta et al. (eds.), Acqua nell'antico Egitto, 2005, pp. 309-18.

${ }^{26}$ Tooley, “Burial Customs”, 1989, p. 253; Leclère, in Muller (ed.), «Maquettes Architecturales», 2001, footnote 12; Spence, in Aston et al. (eds.), Potter's Tree, 2011, pp. 908-09; Müller and Forstner-Müller, in Jiménez-Serrano and von Pilgrim (eds.), From the Delta to the Cataract, 2015, pp. 189-201; Czerny, Tell el-Dab'a XXII, 2015, pp. 352-54, pl. 109.

${ }^{27}$ Leclère, in Muller (ed.), «Maquettes Architecturales», 2001, p. 101; Spence, in Aston et al. (eds.), Potter's Tree, 2011, p. 905. Pot-marks were recognised by Petrie on some of the Rifeh soul houses: Petrie, Gizeh and Rifeh, 1907, pl. XIII. The only exception seems to be an offering tray from Qubbet el-Hawa which bears part of the word imshw: Edel, Felsgräbernekropole der Qubbet el-Hawa, I, 2008, pp. 1626-27, fig. 2.

${ }^{28}$ The ancient Egyptian name for these objects is unknown. Petrie, in Hastings (ed.), Encyclopaedia of Religion and Ethics, XI, 1908-1926, p. 755. Niwinski, ET VIII, 1975, p. 81. This is not to rule out that 
potential words could be proposed after researching the available text corpus.

${ }^{29}$ Minault-Gout, BIFAO 80 (1980), p. 277; Koenig, BIFAO 80 (1980), pp. 35-44.

${ }^{30}$ Leclère, in Muller, «Maquettes architecturales», 2001, p. 120, footnote 82. Kilian, in Kahl et al. (eds.), Seven Seasons at Asyut, 2012, p. 110. Martin-Pardey, Grabbeigaben, Nachträge und Ergänzungen, 1991, p. 147. The result was that the object could have been dated approximately to the Second Intermediate Period, with a range spanning from the late Middle Kingdom to the early New Kingdom.

${ }^{31}$ Tooley has theorised that the growing importance of shabtis outshined wooden models, rapidly replacing them in élite burial equipment. This might also have been the case with offering trays and soul houses. Tooley, in The Oxford Encyclopedia, 2001, p. 426.

${ }^{32}$ Kilian, in Kahl et al. (eds.), Seven Seasons at Asyut, 2012, pp. 110. In Armant, Mond and Myers found 27 trays in two tombs. Even though the tombs were dated to the Thirteenth Dynasty, the trays, although found in situ, were probably in secondary deposition: such a high number of trays in only two tombs could be only explained as an instance of the dumping of earlier material in tombs. Mond and Myers, 1937, Armant, pp. 59-90, p. 63, pl. 22 nos. 5-6.

${ }^{33}$ Del Vesco, in Del Vesco and Moiso, Missione Egitto, 2017, pp. 296-97.

${ }^{34}$ Despite the most recent effort to reconstruct the areas where the Italian Archaeological Mission worked in the necropolis of Asyut, it seems rather unlikely that we will ever be able to relocate the exact findspot of any tray; only the approximate area of excavation can be determined. For the excavations in the Siutian necropolis, see Kahl et al., Asyut, 2019, p. 16, pl. 2, and pp. 76-77, fig. 2 .

${ }^{35}$ Chassinat and Palanque, MIFAO 24 (1911), p. 164, pl. 34.1.

${ }^{36}$ Kamal, ASAE 16 (1916), p. 70, no. 34.

${ }^{37}$ Already noticed by Kilian, in Kahl et al. (eds.), Seven Seasons at Asyut, 2012, p. 112.

${ }^{38}$ Hölzl, Ägyptische Opfertafeln, 2002, Type B+C, pp. 34-38, pp. 51-52, fig. 2a, p. 74.

${ }^{39}$ For examples, see Kuentz, BIFAO 81 (1981), pp. 246 , 251 fig. 6.

${ }^{40}$ S. 7979 and S. 14945: unpublished; EA 46611 and EA 46612: Zitman, The Necropolis of Asyut, 2010, II, pp. 227 and 220, respectively.

${ }^{41}$ Cf. Zitman, The Necropolis of Assiut, 2010, I, pp. 62-63; Kahl et al., Asyut, 2019, p. 283.

${ }^{42}$ Schiestl and Seiler (eds.), Handbook, I, 2010, pp. 394-95, no. 1; Rzeuska, Egyptian Pottery from Asyut, 2017, pp. 192-93, cat. 89.

${ }^{43} \mathrm{~J}$. Kahl et al., in Schiestl and Seiler (eds.), Handbook, II, 2010, pp. 236, 269, fig. 7, nos. 2-3.

${ }^{44}$ Fischer, in Harrassowitz (ed.), Lexikon der Ägyptologie, III, 1980, pp. 686-93.

${ }^{45}$ Del Vesco, in Del Vesco and Moiso (eds.), Missione Egitto, 2017, p. 305, nos. 251-53.

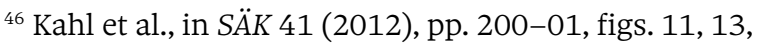
14 (OT1, OT27, OT38); Kilian, in Kahl et al. (eds.), Asyut, Tomb III, 2016, p. 182 (OT14); Kilian, in Kahl et al. (eds.), Seven Seasons, 2012, pl. 8a (OT44).

${ }^{47}$ S. 14943: D’Amicone and Pozzi Battaglia (eds.), Egitto mai visto, 2009, pp. 236-37, no. 8.3; EA 46610: Zitman, The Necropolis of Asyut, II, 2010, p. 222.

${ }^{48}$ Habachi, Tavole d'offerta, 1977, pp. 21-22, CGT 22013 (=S. 8142), 22012 (= S. 8143), 22014 (= S. 8145). (CGT numbers were assigned to objects in the Museo Egizio in the late twentieth and early twenty-first century, mostly concomitantly with their publication).

${ }^{49}$ S. 10647, S. 14848 (?), S. 14941: unpublished. S. 10648: Tooley, “Burial Customs”, 1989, p. 287 no. 11, pl. 82:1. S. 14940: D’Amicone and Pozzi Battaglia (eds.), Egitto mai visto, 2009, pp. 236-37, no. 8.2. EA 46608, EA 46614: Zitman, The Necropolis of Asyut, 2010, II, p. 232; sporadic find: Kamal, ASAE 16 (1916), p. 70, no. 34.

${ }^{50}$ S. 9179: Tooley, "Burial Customs”, 1989, p. 287 no. 10, pl. 81:2; D’Amicone and Fontanella (eds.), Nefer, 2007, p. 57; D’Amicone (ed.), Vita quotidiana, 2006, pp. 120-21 no. 42. S. 14944: D’Amicone and Pozzi Battaglia (eds.), Egitto mai visto, 2009, pp. 236-27, no. 8.3. EA 46617: Tooley, 1989, "Burial Customs", p. 286 no. 2, pl. 79:3; Zitman, 2010, The Necropolis of Asyut, II, p. 224.

${ }^{51}$ Petrie, Dendereh, 1900, pl. XIX no. 2. Now in Manchester (M 2758). http://harbour.man.ac.uk/ mmcustom/Display.php?irn=106238\&QueryPage $=\% 2$ Fmmcustom\%2FEgyptQuery.php accessed on 24 June 2020.

52 https://www.liverpoolmuseums.org.uk/artifact/ offering-tray-2 accessed on 13 May 2019.

${ }^{53}$ P. 5537, S. 14496: unpublished. EA 46607: Zitman, 2010, The Necropolis of Asyut, II, p. 232. EA 46615: Tooley, 1989, “Burial Customs”, p. 286 no. 4, pl. 80:2.

${ }^{54}$ Emery et al., Fortress of Buhen, p. 152 nos. 1459, 1551, 1664, 1695; see also pl. 55 and pl. 104.

${ }^{55}$ S. 14949: unpublished. OT18: Kilian, in Kahl et al. (eds.), Asyut, Tomb III, 2016, p. 184. OT22+29: ibid., pp. 185, 187, p. 195 pl. h. OT24: ibid., p. 186.

${ }^{56}$ S. 8141: D’Amicone and Pozzi Battaglia (eds.), Egitto mai visto, 2009, pp. 236-37, no. 8.3. EA 46609, EA 46613: Zitman, The Necropolis of Asyut, 2010, II, p. 217. EA 46616: Tooley, “Burial Customs”, 1989, p. 286 no. 3, pl. 80:1; Zitman, The Necropolis of Asyut, 2010, II, p. 225. EA 46618: Zitman, The Necropolis of Asyut, 2010, II, p. 225. EA 46619: unpublished. EA 47372: Zitman, The Necropolis of Asyut, 2010, II, p. 225.

${ }^{57}$ Tooley, “Burial Customs", 1989, p. 286 no. 3, pl. 80 fig. 1.

${ }^{58}$ Petrie, Kahun, 1890, pl. XIII no. 102; Petrie, Illahun, 1891, pl. IV, no. 20.

${ }^{59}$ OT3+OT16+OT25+OT33+OT34: Kilian, in Kahl et al., Seven Seasons, 2012, pl. 8e and pl. 9b; Kilian, in Kahl et al. (eds.), Asyut, Tomb III, 2016, pp. 178, 183, 187, 188, 189, p. 191 pl. a. OT10+OT17+OT21: Kilian, in Kahl et al. (eds.), Seven Seasons, 2012, pl. 9c; Kilian, in Kahl et al. (eds.), Asyut, Tomb III, 2016, pp. 181, 183, 185, p. 193 pl. e, p. 194 pl.f.

${ }^{60}$ EA 46620: unpublished. EA 46621, EA 46622: Kilian, in Kahl et al. (eds.), Seven Seasons, 2012, pl. 9c; Kilian, in Kahl et al. (eds.), Asyut, Tomb III, 2016, pp. 181, 183, 185, p. 193 pl. e, p. 194 pl. f. OT4+OT13+OT35: 
ibid., pp. 178, 182, 189, p. 192 pl. b. OT5+OT9: ibid., pp. 179, 181, p. 192 pl. c. OT6: ibid., p. 179; Kilian, in Kahl et al. (eds.), Seven Seasons, 2012, p. 113. fig. 7. OT7+OT20: Kilian, in Kahl et al. (eds.), Asyut, Tomb III, 2016, pp. 180, 184, p. 193 pl. d. OT8: ibid., p. 180. OT12+OT30+OT31+OT32: ibid., pp. 182, 188, p. 195 pl. g. OT15: ibid., p. 182. OT19: ibid, p. 184. OT23: ibid., pp. 185-86. OT36: ibid., p. 182. OT56, OT58: ibid., p. 190. OT26: Kahl et al., SÄK 41 (2012), pp. 200-01, fig. 12. OT41: Kilian, in Kahl et al. (eds.), Seven Seasons, 2012, pl. 9a; OT40: ibid., p. 112, fig. 6.

${ }^{61}$ Only mentioned by Tooley, "Burial Customs”, 1989, pp. 286-87 nos. 6, 8, 9. Other unmentioned trays might exist.

62 Tooley, “Burial Customs”, 1989, pp. 264-65, nos. 3-5.

${ }^{63}$ For a detailed summary of the excavation campaigns conducted by the M.A.I. in Gebelein see Moiso, Storia del Museo, 2016, p. 64; Del Vesco, in Museo Egizio, 2015, pp. 70-71.

${ }^{64}$ Currently registered as S. 11966 (?), the number without the question mark having been assigned to a soul house, as verified in the original inventory of the Italian mission: here S. 11966 is indeed a fragmentary offering tray and not a soul house.

65 "Seguono molti materiali, venuti in luce dispersi, ossia da sepolture già violate." Schiaparelli, Inventario Manoscritto.

${ }^{66}$ S. 16032: Museo Egizio, p. 72 nos. 60-62. S. 16035: unpublished.

${ }^{67}$ Mond and Myers (eds.), Cemeteries of Armant, 1937, pl. 22, at the centre of fig. 6 .

${ }^{68}$ Manchester M 3773 is said to come from Esna, but the tray is not included in Downes, Excavations, 1974, p. 94, fig. 63. http://harbour.man.ac.uk/ emuweb/pages/common/imagedisplay.php?irn= 1052\&reftable $=$ ecatalogue $\&$ refirn $=108165$ accessed on $10 / 05 / 2019$.

${ }^{69}$ https://www.britishmuseum.org/collection/object/Y_ EA43446 accessed on 24/06/2020.

${ }^{70}$ http://www.matriznet.dgpc.pt/MatrizNet/Objectos/ ObjectosConsultar.aspx?IdReg=120131 accessed on 24/06/2020.

${ }^{71}$ Edel, Felsgräbernekropole der Qubbet el-Hawa, II, 2008, p. 1289 , fig. 10.

72 Petrie, Qurneh, 1909, pl. XX-XXI.

${ }^{73}$ The trays were found in situ in two rock-cut tombs, together with pottery dating to the First Intermediate period. Arnold, MDAIK 29 (1973), pp. 27-30, pl. LXVIII b (N 3.1).

${ }^{74}$ Dated to the Middle Kingdom; Budka, Bestattungsbrauchtum, 2010, p. 743, fig. 329, pl. 57b.

${ }^{75}$ S. 11963: D’Amicone and Pozzi Battaglia (eds.), Egitto mai visto, 2009, pp. 236-37, no. 8.2. S. 11964 and S. 11967: unpublished.

${ }^{76}$ S. 16034: Museo Egizio, 2015, p. 72 nos. 60-62. All the others are unpublished.

${ }^{77}$ Although two very similar trays, UC 18420 and UC 18421 in the Petrie Museum of Egyptian Archaeology, are said to have come from Elkab, they were actually only purchased by Petrie in that locality, not found by him during excavations there. Petrie, Funeral Furniture, 1937, p. 4, nos. 46-47. Tooley, "Burial
Customs, 1989, p. 260, nos. 4-5.

${ }^{78}$ Mond and Myers (eds.), Cemeteries of Armant, 1937, pl. 22, figs. 5-6.

${ }^{79}$ Inv. nos. 1973.1.351, 1973.1.355, 1973.1.357, and 1973.1.360. Bienkowski and Southworth, Egyptian Antiquities in the Liverpool Museum, 1986, p. 31.

80 https://www.britishmuseum.org/collection/object/Y EA21702 accessed on 23/06/2020.

${ }^{81}$ https://www.liverpoolmuseums.org.uk/artifact/ offering-tray-12 accessed on 23/06/2020.

${ }^{82}$ Schneider and Raven, Egyptische Oudheid, 1981, no. 37c.

${ }^{83}$ http://harbour.man.ac.uk/emuweb/pages/common/ imagedisplay.php?\&irn=131774\&reftable=ecatalogue \&refirn $=106239 \&$ size $=360 \times 480$ accessed on 23/06/2020.

${ }^{84}$ http://harbour.man.ac.uk/emuweb/pages/common/ imagedisplay.php?irn=131766\&reftable=ecatalogue $\&$ refirn=106241 accessed on the 23/06/2020.

85 https://www.uvaerfgoed.nl/beeldbank/en/ allardpiersonmuseum/xview/?identifier=hdl:11245 /3.1679; metadata=offerbord\#page/0 accessed on the 23/06/2020. For the provenance, see Lusing Scheurleer, Geschenk van de Nijl, 1992, p. 90 cat. 58.

${ }^{86}$ Seipel, Ägypten. Götter, Gräber und die Kunst, 1989, p. 97 fig. $63 \mathrm{~b}$.

${ }^{87}$ Tooley only mentions a soul house that is now in Brussels, inv. no. E2283.

${ }^{88}$ The only exception seems to be one tray (reconstructed from several fragments) and three fragments of trays, recovered in the Middle Kingdom (early Twelfth Dynasty) temple of Ezbet Ruschdi, near Tell el-Dab'a. While this find should move the northernmost limit of distribution of trays to the Delta, it should be considered nonetheless as an exceptional occurrence in an unusual context for an offering tray, as trays are usually found in necropoleis or town areas, but not in temples. Czerny, Tell el-Dab'a XXII, 2015, pp. 352-54, pl. 109.

${ }^{89}$ Both published in D'Amicone and Fontanella (eds.), Nefer, 2007, p. 257, and D'Amicone (ed.), Vita quotidiana, 2006, pp. 120-01 n. 42.

${ }^{90}$ Petrie, Dendereh, 1900, pl. XIX, no. 6.

${ }^{91}$ Petrie, Qurneh, 1909, pl. XXI nos. 611, 612, 613. Arnold, MDAIK 29 (1973), pl. LXVIII, N 3.1.

${ }^{92}$ Museo Egizio, p. 5536; S. 11963; S. 11965; S. 14259. S. 11964; S. 11967.

${ }^{93}$ Liverpool Museum, 1973.1.354. https://www. liverpoolmuseums.org.uk/artifact/offering-tray-8, accessed on 13/05/2019; D. Downs, Excavations, 1974, p. 94, fig. 63.

${ }^{94}$ Sometimes even four.

${ }^{95}$ Petrie, Qurneh, 1909, pl. XXI nos. 611, 621, 626, $627,628,629,630,631$. Carter (ed.), Explorations at Thebes, 1912, pl. XVIII, fig. 3, no. 16.

${ }^{96}$ Petrie, Qurneh, 1909, pl. XXI, nos. 618-619.

${ }^{97}$ Edel, Felsgräbernekropole der Qubbet el-Hawa, II, 2008, p. 1289, figs. 8-9, p. 1310, figs. 10-12; Edel, Felsgräbernekropole der Qubbet el-Hawa, III, 2008, p. 1768 , fig. 26, p. 1781, fig. 64 .

${ }_{98}$ Petrie, Dendereh, 1900, pl. XIX, no. 6; Petrie, Qurneh, 1909, pl. XXI, no. 613; The trays look very similar, 
at least as far the drawings in Petrie's publications suggest. Unfortunately, I have not been able to trace these pieces in any collection. Their current location appears to be unknown.

\section{Bibliography}

Arnold, D., "Bericht über die vom Deutschen

Archäologischen Institut Kairo im Winter 1971/72 in El-Târif durchgeführten Arbeiten”, MDAIK 29 (1973), pp. 135-62.

Barahona Mendieta, Zulema, “ $11^{\text {th }}$ Dynasty Pottery Below the Courtyard of Djehuty (TT 11)”, BCE 28 (2018), pp. 171-81.

Bienkowski, P. and E. Southworth, Egyptian Antiquities in the Liverpool Museum. I: A List of the Provenanced Objects, Warminster 1986.

Borghouts, J.F., "Libation”, in W. Helck and E. Otto (eds.), LÄ III (1980), pp. 1014-015.

Bourriau, J., "The Vienna System in Retrospect: How Useful Is It?”, in Z. Hawass, and J.E. Richards (eds.), The Archaeology and Art of Ancient Egypt: Essays in Honor of David B. O'Connor (CASAE 36), Le Caire 2007, II, pp. 137-44.

Budka, J., Bestattungsbrauchtum und Friedhofsstruktur im Asasif: eine Untersuchung der spätzeitlichen Befunde anhand der Ergebnisse der österreichischen Ausgrabungen in den Jahren 1969-1977 (UZK 34), Wien 2010.

Carter, H. and the Earl of Carnarvon (eds.), Five Years' Explorations at Thebes: A Record of Work Done 1907-1911, London 1912.

Chassinat, M.E. and C. Palanque, Une campagne de fouilles dans la nécropole d'Assiout, Cairo 1911.

Czerny, E., Tell el Dab'a XXII. „Der Mund der beiden Wege“. Die Siedlung und der Tempelbezirk des Mittleren Reiches von Ezbet Ruschdi, Teil I: Text, Teil II: Abbildungen Tafeln - Pläne - Profile - Schnitte (UZK 38), Wien 2015.

D’Amicone, E. and E. Fontanella (eds.), Nefer: la donna nell'antico Egitto. Milano, Palazzo Reale 27 gennaio - 9 aprile 2007, Milano 2007.

D’Amicone, E. and M. Pozzi Battaglia (eds.), Egitto mai visto: la montagna dei morti. Assiut quattromila anni fa, Trento 2009.

Del Vesco, P. and B. Moiso (eds.), Missione Egitto 19031920: L'avventura archeologica M.A.I. raccontata, Torino and Modena 2017.

Downes, D., The Excavations at Esna 1906-1906, Warminster 1974.

Edel, E., Die Felsgräbernekropole der Qubbet el Hawa bei Assuan, I. Abteilung: Architektur, Darstellungen, Texte, archäologischer Befund und Funde der Gräber [QH 24 - QH 209], Paderborn - Munchen - Wien - Zurich 2008.

Emery, H., S. Smith, A. Millard, and R.M.F. Preston (eds.), The Fortress of Buhen: The Archaeological Report (EES ExcMem 49), London 1979.

Fischer, H., “Kopfstütze”, in W. Helck and E. Otto (eds.), $L \ddot{A}$ III (1980), pp. 686-93.

Habachi, L., Tavole d'offerta, are e bacili da libagione, n. 22001-22067 (Catalogo del Museo Egizio di Torino, serie seconda - collezioni 2), Torino 1977.

Hölzl, R., Ägyptische Opfertafeln und Kultbecken: eine Form- und Funktionsanalyse für das Alte, Mittlere und Neue Reich (Ḧ̈B 45), Hildesheim 2002.

Hölzl, R., "Libation Basins from the Old to the New Kingdom: Practical Use and Religious Significance”, in A. Amenta, M.M. Luiselli, and M.N. Sordi (eds.), L'Acqua nell'antico Egitto: vita, rigenerazione, incantesimo, medicamento. Proceedings of the First International Conference for Young Egyptologists, Italy, Chianciano Terme, October 15-18, 2003, Roma 2005, pp. 309-17.

Kahl, J., E. Engel, and L. Sanhueza-Pino, "Pottery from Asyut”, in R. Schiestl and A. Seiler (eds.), Handbook of Pottery of the Egyptian Middle Kingdom. Volume II: The Regional Volume, Wien 2012, pp. 261-71.

Kahl, J., M. El-Khadragy, U. Verhoeven, M. Abdelrahiem, M. van Elsbergen, H. Fahid, A. Kilian, C. Kitagawa, T. Rzeuska, and M. Zöller-Engelhardt, "The Asyut Project: Ninth Season of Fieldwork (2011)”, SAK 41 (2012), pp. 189-235.

Kahl, J., A.M. Sbriglio, P. Del Vesco, and M. Trapani, Asyut: The Excavations of the Italian Archaeological Mission (1906-1913) (Studi del Museo Egizio 1), Modena 2019.

Kamal, A., "Fouilles à Deir Dronka et à Assiout (19131914)”, ASAE 16 (1916), pp. 65-114.

Kilian, A., "Pottery Offering Trays: General Observations and New Material from Asyut", in J. Kahl, M. ElKhadragy, U. Verhoeven, and A. Kilian (eds.), Seven Seasons at Asyut: First Results of the Egyptian-German Cooperation in Archaeological Fieldwork. Proceedings of an International Conference at the University of Sohag, 10th-11th of October, 2009, Wiesbaden 2012, pp. 105-18.

Kilian, A., “Offering Trays”, in J. Kahl, N. Deppe, D. Goldsmith, A. Kilian, C. Kitagawa, J. Moje, and M. Zöller-Engelhardt, Asyut, Tomb III: Objects (Part 1) (The Asyut Project 3), Wiesbaden 2016, pp. 173-95.

Koenig, V. and Koenig, Y., “Trois tombes de la Première Période Intermédiare à Balat”, in BIFAO 80 (1980), pp. 35-44.

Kuentz, C., "Bassins et tables d'offrandes", BIFAO 81 (1981; Supplément : Bulletin du centenaire), pp. 243-82.

Leclère, F., "Les « maisons d’âme » égyptiennes : une tentative de mise au point”, in B. Muller (ed.), "Maquettes architecturales" de l'antiquité : regards croisés (Proche-Orient, Égypte, Chypre, bassin égéen et Grèce, du Néolithique à l'époque hellénistique). Actes du colloque de Strasbourg, 3-5 décembre 1998, Paris 2001, pp. 99-122.

Lunsingh Scheurleer, R.A., Egypte: Geschenk van de Nijl, Amsterdam 1992.

Marini, P., "I contenitori di ushabti: funzioni e concezioni" (doctoral dissertation, Università di Pisa), Pisa 2016.

Martin-Pardey, E., Pelizaeus-Museum, Hildesheim, Lieferung 6: Grabbeigaben, Nachträge und Ergänzungen (CAA), Mainz am Rhein 1991.

Moiso, B., La storia del Museo Egizio, Modena 2016.

Mond, R. and O. Myers (eds.), Cemeteries of Armant I, Oxford 1937.

Müller, W. and I. Forstner-Müller, "A Newly Discovered 'Soul House' in Assuan”, in A. Jiménez-Serrano and C. von Pilgrim (eds.), From the Delta to the Cataract: 
Studies Dedicated to Mohamed el-Bialy, Leiden 2015, pp. 189-201.

Museo Egizio, Torino and Modena 2015.

Niwinski, A., "Plateaux d'offrandres et « maisons d'âmes » : genèse, évolution et fonction dans le culte des morts au temps de la XIIe dynastie" ÉtudTrav 8 (1975), pp. 103-04.

Nordström, H. and J. Bourriau, “The Vienna System”, in Do. Arnold and J. Bourriau (eds.), An Introduction to Ancient Egyptian Pottery, Mainz 1993, pp. 168-82.

Pérez Die, M.d.C., "The Cemetery of the First Intermediate Period / Early Middle Kingdom in Herakleopolis Magna”, unpublished paper delivered at the conference Current Research in Egyptology 2019 (Alcalá de Henares, Spain, 18 June 2019).

Petrie, W.M.F., Dendereh, London 1900.

Petrie, W.M.F., Gizeh and Rifeh (BSAE 13), London 1907. Petrie, W.M.F., Kahun, Gurob, and Hawara, London 1890.

Petrie, W.M.F., Illahun, Kahun and Gurob: 1889-90, London 1891.

Petrie, W.M.F., Qurneh (BSAE 16), London 1909.

Petrie, W.M.F., Funeral Furniture and Stone Vases, London 1937.

Petrie, W.M.F., "Soul-House”, in J. Hastings (ed.) Encyclopaedia of Religion and Ethics, XI, New York 1908-1926, pp. 755-56.

Raven, M.J., "Numbering Systems in the Egyptian Department of the Rijksmuseum van Oudheden at Leiden”, in OMRO 72 (1992), pp. 7-14.
Ridley, R.T., Napoleon's Proconsul in Egypt: The Life and Times of Bernardino Drovetti, London 1998.

Rzeuska, T.I., Chronological Overview of Pottery from Asyut: A Contribution to the History of Gebel Asyut al-gharbi (The Asyut Project 7), Wiesbaden 2017.

Schiestl, R. and A. Seiler, Handbook of Pottery of the Egyptian Middle Kingdom. Volume I: The Corpus Volume (ÖAW 72), Wien 2012.

Schneider, H.D. and M.J. Raven, De Egyptische Oudheid: een inleiding aan de hand van de Egyptische verzameling in het Rijksmuseum van Oudheden to Leiden, 's-Gravenhage 1981.

Seipel, W., Ägypten, Götter, Gräber und die Kunst, 4000 Jahre Jenseitsglaube, I, Linz 1989.

Slater, R.A., "The Archaeology of Dendereh in the First Intermediate Period" (dissertation, University of Pennsylvania 1974).

Tooley, A.M.J., "Middle Kingdom Burial Customs" (dissertation, University of Manchester 1989).

Tooley, A.M.J., "Models”, in D.B. Redford (ed.), The Oxford Encyclopedia of Ancient Egypt, Oxford 2001, pp. 424-28.

Waksman, Y., "Provenance Studies: Productions and Compositional Groups", in A.M.W. Hunt, The Oxford Handbook of Archaeological Ceramic Analysis, Oxford 2017, pp. 148-61.

Zitman, M., The Necropolis of Assiut: A Case Study of Local Egyptian Funerary Culture from the Old Kingdom to the End of the Middle Kingdom (OLA 180), Leuven 2010. 